\title{
8 On the obligatory use of a nasalising relative clause after an adjectival antecedent in the Old Irish glosses
}

\section{Introduction}

According to Thurneysen (GOI $§ 383$ ), "an adverb formed from the dative of the adjective cannot be used in periphrasis with the copula before its clause ... [Instead,] the adverbial form is replaced by the nominative sg. neuter of the adjective ... ., and a nasalizing relative clause follows". The same cleft-sentence construction is referred to in the second part of $\S 498,{ }^{1}$ and the examples given ${ }^{2}$ are:

(1) arndip maith n-airlethar a muntir so.that-COP ${ }_{\text {3SG.PRES.SUBJ }} \operatorname{good}_{\text {NOM.SG.NEUT }}{ }^{\text {NAS }}$ care $_{\text {3SG.PRES.SUBJ }}$ his household ${ }_{\text {ACC }}$ 'that he care well for his household' (Wb. 28b32)

(lit. 'so that it may be good/a good thing how he cares ...' [GOI §383] as opposed to lit. '. . . well that . ..,' with an adverbial antecedent)

(2) is lèrithir insō no nguidim-se dīa $\mathrm{COP}_{\text {3SG.PRES }}$ zealous $_{\mathrm{EQ}}$ the $=$ this $_{\mathrm{ACC}} \mathrm{PV} \cdot{ }^{\text {NAS }}$ beseech $_{1 \mathrm{SG} . \mathrm{PRES}}=1 \mathrm{SG} \mathrm{God}_{\mathrm{ACC}}$ 'as zealously as this do I beseech God' (Wb. 27 19 ; author's trans.)

(3) is dínnimu do-ngní alaill $\mathrm{COP}_{3 \text { SG.PRES }}$ zealous $_{\mathrm{COMP}} \mathrm{PV} \cdot{ }^{\mathrm{NAS}} \mathrm{do}_{3 \mathrm{SG} . \mathrm{PRES}}$ other $_{\mathrm{ACC}}$ 'It is more carelessly that he makes the other.' (Wb. $4^{\mathrm{c}} 33$ )

Moreover, while "a nasalizing relative clause can be replaced by a formally independent (i.e. principal) clause in almost every instance, ... this is not

\footnotetext{
1 A more detailed description and evaluation of this construction is given by Mac Coisdealbha (1998: 155-157; cf. 257, n. 82). On some of his interpretations of specific cases see individually below.

2 Here quoted from Thes., with added editorial macrons and, for these introductory examples, word division and hyphenation. For the length in in $s \bar{o}$ and words of similar structure, see Breatnach (2003).
}

Ә Open Access. () 2020 Jürgen Uhlich, published by De Gruyter. (c) BY-NC-ND This work is licensed under the Creative Commons Attribution-NonCommercial-NoDerivatives 4.0 International License. 
possible . . . in the constructions described in $\S \S 499,{ }^{3} 501,{ }^{4}$ nor after a neuter adjective in periphrasis with the copula (§ 498)” (GOI § 505).

According to Thurneysen, therefore, the construction under consideration here presents one of the very few grammatical contexts in which a nasalising relative clause is predictable. ${ }^{5}$ If borne out by the detailed re-examination of the material undertaken here, this would allow a confident assessment - within this particular context - of how the formal characteristics of the nasalising relative construction may be affected by adverse linguistic developments. To give two examples: (i) it would be possible to ascertain that in a putative case ${ }^{\star}$ is cosmail asbeir 'similarly he says', it is (at least statistically) more likely that the expected relative nasalisation in asmbeir has been suppressed in interconsonantal position than that this should be counted among the symptoms for the nasalising relative construction as such already being in the process of loss (see also the discussion in Roma 2018a, and Roma, this volume); ${ }^{6}$ (ii) being able to rely securely on the presence of a nasalising relative construction would also allow one to draw conclusions on the use of the different classes of infixed pronouns in relative sentences overall. For the only other construction that

3 The specific figura etymologica construction of a verb connected to its own verbal noun as antecedent in an adverbial relative construction (of the pattern "the deliverance wherewith he delivered"), for which see further Stüber (2010-2012).

4 With an object antecedent, where the nasalising relative alternates synchronically with a leniting relative; see Schrijver (1997b: 91-113).

5 This ruling has been variously questioned by citing formally deviant examples; see Pedersen (1899: 391, 413, 414), Mac Coisdealbha (1998: 155), Ó hUiginn (1986: 58) and Isaac (in Mac Coisdealbha 1998: 257). Their objections and supporting examples will be assessed in sections 5 and 6.

6 The very initial symptoms of this linguistic innovation are described in GOI $\S 506$. For the (partly sporadic) loss of interconsonantal nasals see GOI $\S 180$ (2-3); Thurneysen (1905: 1-2), cf. Quin (1979-1980: 256). To the examples given there need to be added cases that show that even a grammatically functional nasal could be suppressed in this way (as is merely hinted at in GOI $\S 504$ [c]): thus, while there are numerous instances where nasalisation is expressed between consonants, such as arnach $\boldsymbol{n}$ dermandadar dia 'that God should not forget him' (Ml. $32^{\mathrm{d}} 5$ ), its loss is seen in connach[n]gabad huall de 'that pride might not seize him' (Ml. 69 ${ }^{\mathrm{a}} 17$ ); cf. further the parallel examples of indhuall rodngabsom 'the pride that had seized him' (Ml. $61^{\mathrm{a}} 1$ ), vs. huanduaill rod[n]gab 'by the pride that seized him' (Ml. 49 3 ) ['[n]' in both cases inserted by me]. Accordingly, while Schrijver (1997b: 97, 100) differentiates between cases like asrect maid asmbeir do airiuc túas, 'that it is a good law, which he says above he has found' (Wb. $3^{\mathrm{d}} 10$ ), and taidbsin afirinne asber 'it is an exposition of his righteousness which he utters' (Ml. 40 ${ }^{\mathrm{a}} 15$ ), as showing variation between nasalising and leniting relatives after object antecedents, the second example - together with numerous others of similar structure listed in his footnotes (Schrijver 1997b: 97, nn. 1-2, 100, nn. 1, 3-5) - may also be taken as showing suppression of nasalisation. 
according to Thurneysen strictly predicts a nasalising relative, the adverbial figura etymologica, a full re-examination of the Old Irish material has already been carried out by Stüber (2010-2012), confirming that the nasalising relative is indeed compulsory, and while there are no instances of the pattern ${ }^{\star} a s[\mathrm{~m}]$ beir in her collection, a couple of cases that involve infixed pronouns are worthy of note (and will be addressed below).

\section{Differentiations}

\subsection{Adverbial cleft sentence}

Before addressing the adjectival cleft construction itself, it will be useful to differentiate it from some other patterns that are similar in form or in meaning. Beginning with the latter, the observed rule (see also section 3) that a deadjectival adverb cannot be fronted in a cleft sentence means that the adverbial cleft pattern, consisting of an adverbial expression followed by a non-relative verb, is confined to prepositional phrases (for more information, see Griffith's chapter, this volume) and lexicalised adverbs, ${ }^{7}$ compare:

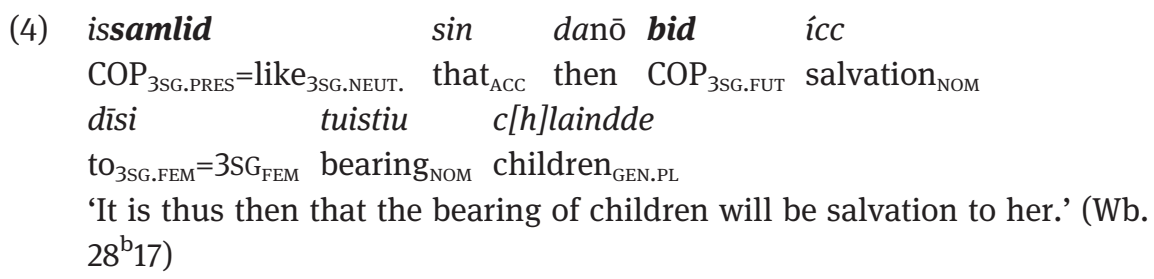

Thus, while the adverbial element is contained in the fronted item samlid 'like it, thus', the same is not permissible with, for instance, (in/co) maith 'well' (see GOI $\S \S 379,381$ ), and instead of tis (in/co) maith airlithir, literally 'it is well that he cares', the adverbial element is shifted to the relative connection itself (= the relative pronoun of other languages), resulting in is maith n-airlethar, literally 'it is good how he cares'.

7 As well as subordinate clauses, see GOI § 814. 


\subsection{Adjective + subject complement clause}

Additionally, a fronted adjective may not only be the antecedent of an adverbial relative, but also of a subject clause (with the meaning '[the fact] that . . .'), for which a nasalising relative is merely an option (cf. GOI $\S 503$ ), yielding a formally similar or indeed identical construction:

(5) a. with non-relative continuation, copula:

\begin{tabular}{|c|c|c|}
\hline is & follus & trisodin \\
\hline $\mathrm{COP}_{3 \mathrm{SG} . \mathrm{PRES}}$ & clear $_{\text {NOM.SG.NEUT }}$ & $\overline{\text { through }}=$ that $_{\mathrm{ACC}} \mathrm{COP}_{\text {3SG.PRES }}$ \\
\hline asintsalm & hōdūaid & $d[u]$ uic \\
\hline out-the $=$ psalm ${ }_{\text {DAT }}$ & from $=$ David $_{\mathrm{DAT}}$ & PV.bring ${ }_{\text {AUG.3SG.PRES }}$ \\
\hline
\end{tabular}

'It is clear thereby that it is out of the psalm from David that he brings ...'(Ml. 25 $\left.5^{\mathrm{d}} 18\right)$

b. with non-relative continuation, stressed verb:

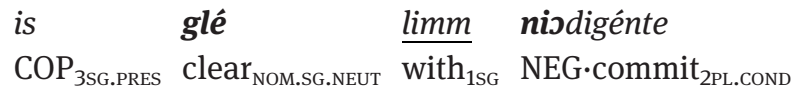

'It is clear to me that ye would not commit. . .' (Wb. $9^{\mathrm{d}} 9$ )

c. with relative continuation, copula:

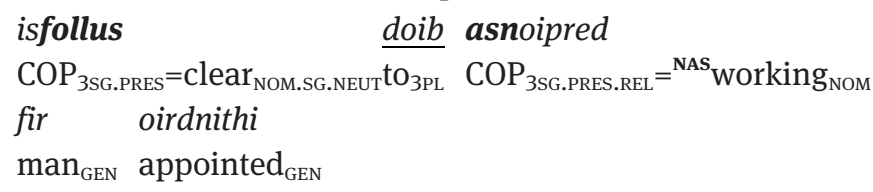

'It is manifest to them that it is the working of a supreme being.' ( $\mathrm{Wb}$. $\left.1^{\mathrm{b}} 14\right)$

d. with relative continuation, stressed verb:

Is

follus rundgabsat

$\mathrm{COP}_{\text {3SG.PRES }}$ clear $_{\text {NOM.SG.NEUT }} \quad \mathrm{AUG}^{\mathrm{NAS}}{ }^{\mathrm{NSG}} \mathrm{NEUT}_{\mathrm{NEU}} \cdot$ take $_{\text {3PL.PRET }}$ terchoiltisiu indiumsa

thy=deterimations NOM.PL $_{\text {PL }}=2 \mathrm{SG} \quad$ in $_{1 \mathrm{SG}}=1 \mathrm{SG}$

'It is clear that Thy determinations are in me.' (Ml. $74^{\mathrm{d}} 7$ )

Here, both semantic considerations and, in three cases, the intervening elements (underlined) make it clear that these are not an adjectival cleft 'it is clearly/in a clear fashion that . . .', literally 'it is clear how . . .', but non-cleft copula sentences with a complement clause as subject: 'it is clear that . . . '. The distinction to be observed is thus between '(the circumstance) by which' of the construction under discussion and '(the fact) that' with a subject complement clause. In individual cases - particularly when the main verb is not the copula - doubts could arise as to which of the two constructions is intended; compare: 

(6) is
derb
contoroe
farao
achrid
$\mathrm{COP}_{\text {3SG.PRES }}$ certain $_{\text {NOM.SG.NeUT }}$
do miscuis macc
PV·turn AUG.3SG.PRET $_{\text {P }}$
Pharaoh $_{\mathrm{NOM}}$ his=heart ${ }_{\mathrm{ACC}}$
to hatred ${ }_{\text {DAT }}$ children GEN.PL $^{{ }^{N A S}}$ Israel $_{\text {GEN }}$
'Certainly Pharaoh had turned his heart to hatred of the Children of Israel.' (Ml. 123 ${ }^{\mathrm{b}} 7$ ) gl. bene conuertit Pharao cór suum ad odiendum popu- lum, quem ...

Here only semantic considerations suggest that the concept of 'certainly' (with an English adverb rendering the Old Irish adjective derb) is meant to qualify the implied superordinate verb (e.g. in *'One can state with certainty that . . .') rather than the verb of the associated sentence ('had turned in a certain way'). Similarly, bene convertit of the Latin original can hardly stand for 'he turned well' = 'he did well to turn', but must mean elliptically 'it may be well stated that . . . ' The following gloss appears to be more ambiguous:

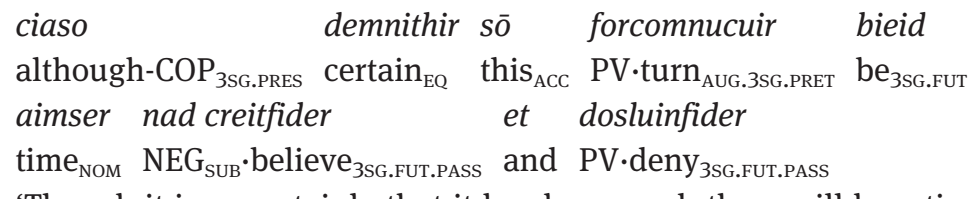

'Though it is so certainly that it has happened, there will be a time when it will be disbelieved and denied.' (Wb. $28^{\mathrm{c}} 14$ )

As presented in Thes., this glosses Spiritus [autem] manifeste dicit, quia ..., 'Now the Spirit expressly says that . . .', suggesting that here, too, demnithir sō 'as certain as this' qualifies an implied superordinate verb (e.g. in *'one can say as certainly as this that ...'), just as manifeste qualifies dicit, in which case 'certainly' in Thes. would have to be changed to 'certain'. However, CharlesEdwards (1971) has shown that the full Latin context, quoted only partially in Thes., includes the previous sentence (1 Timothy 3:16-4:1):

(8) et manifeste magnum est pietatis sacramentum quod manifestatum est in carne et iustificatum est in spiritu apparuit angilis praedicatum est gentibus creditum est in hoc mundo adsumptum est in gloria[.] Spiritus manifeste dicit quia in novissimis temporibus discendent quidam a fide . . .

8 This follows the Würzburg manuscript itself (see Stern 1910: folio $28^{\mathrm{va}} 17-23$, here given with slight normalisation, mainly concerning abbreviations and word-internal spaces), which deviates from that in the Vulgate (Weber 2007) in some minor detail only. 
'Great indeed, we confess, is the mystery of godliness: He was manifested in the flesh, vindicated by the Spirit, seen by angels, proclaimed among the nations, believed on in the world, taken up in glory. Now the Spirit expressly says that in later times some will depart from the faith . . .' (ESV).

In this, the Old Irish equative demnithir sō in fact refers back to the first manifeste, ${ }^{9}$ which qualifies the following statement directly (literally 'and manifestly great is ... ') and not via a superordinate verbum dicendi, meaning that the intended construction is an adjectival cleft after all, including the correct translation 'certainly'. As a final example, both constructions are found in:

(9) is

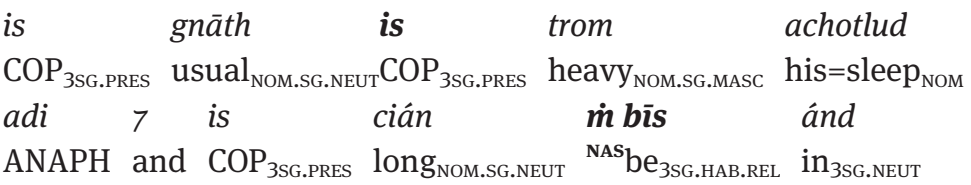

'His sleep is wont to be heavy and he is wont to be long therein.' (Ml. $\left.100^{\mathrm{a}} 10\right)$

(lit. 'it is usual that . . . and it is long how . . .' / or: 'a long time by which . . .')

\subsection{Substantivised adjective as object antecedent}

In another superficially similar construction, the connection between the fronted adjective and the relative clause cannot be interpreted adverbially; rather, the predicate adjective serves as a substantive and is interpreted as the object of the headless relative clause:

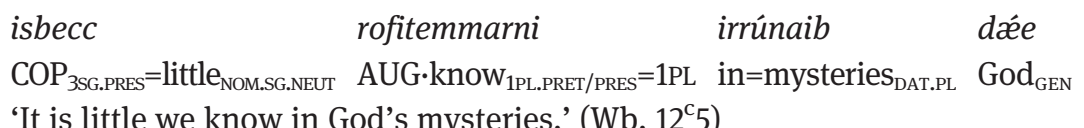

9 Charles-Edwards (1971: 189) argues further that "demnithir in the Irish gloss refers to the first manifeste (the one not given in the Thesaurus) and compares it with the second manifeste. The glossator's point is that it is just as certain a scriptural truth that Christ was incarnated etc. as that some will lapse from the faith. The two are equally manifest”. This, however, is not borne out by the text, where demnithir sō, in referring to the first manifeste as 'as certain as stated above,' does so by qualifying forcomnucuir 'it has happened,' without any connection to the second part of the gloss that alone corresponds to what follows the second manifeste. 
The preposition in i rrúnaib 'in the mysteries' here necessitates this interpretation, as opposed to a putative adjectival cleft *is becc ro-fitemmar-ni rúna dé, literally 'it is small how we know God's mysteries'. The same construction is editorially assumed in:

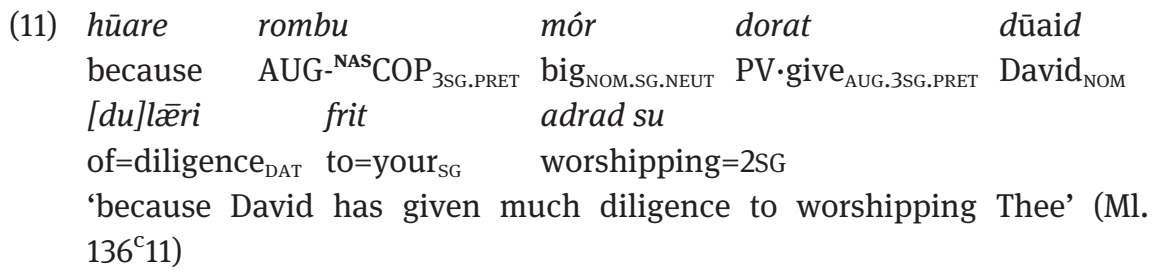

But the emendation in Thes. is not necessary if instead the manuscript reading is taken as an adjectival cleft, with an English adverbial translation 'it is greatly that David has given diligence ...' (Griffith and Stifter 2013). On the other hand, this is not possible (pace Mac Coisdealbha 1998: 155) in the following case:
(12) ismó
rochéess
crīst airi
i. báas
$\mathrm{COP}_{\text {3SG.PRES }}=$ more AUG. ${ }^{\text {LEN }}$ suffer $_{3 \mathrm{SG} . \mathrm{PRET}}$ Christ $_{\text {NOM }}$ for 3SG.MASC $_{\text {i.e. death }}$ NOM
'It is more that Christ has suffered for him, to wit, death.' (Wb. $6^{\mathrm{c}} 8$ )

The main sentence as far as airi could be understood as an adjectival cleft with adverbial meaning, 'it is more greatly that Christ has suffered for him', but only if an innovatory leniting relative is admitted (cf. GOI §506). This, however, would leave the added explanatory object báas out of construction. Therefore, Sims-Williams (1984: 193, albeit without quoting .i. báas in support), is right in understanding mó "substantivally as object antecedent ... 'it is a greater (thing) (more) that Christ has suffered for him'” (see also Griffith's contribution in this volume).
(13) bid mó dongēnaesiu oldaas rofoīded cucut $\mathrm{COP}_{\text {3SG.FuT }}$ more PV. ${ }^{\mathrm{NAS}} \mathrm{do}_{2 \mathrm{SG} . \mathrm{FUT}}=2 \mathrm{SG}$ 'than' $\mathrm{AUG} \cdot$ send ${ }_{3 \mathrm{SG} . \text { PRET.PASS }}$ to $_{2 \mathrm{SG}}$ 'Thou wilt do it more than has been sent to thee.' (Wb. 32 $\left.{ }^{\mathrm{a}} 25\right)$, gl. sciens quoniam et super id quod dico facies (Philemon 21) 'knowing that you will do even more than I say' (ESV).

The translation offered in Thes. presupposes reading dongēnae as don[d]gēnae with an infixed pronoun. However, Pedersen (1899: 391) suggests that "dagegen 
gehört bid mó dongenaesiu 32 a 25 eher in $\S 71$ [however, bid mó dongenaesiu $32^{\mathrm{a}} 25$ belongs rather to $\S 71$ ]", referring to page 392f. where he deals with nasalising relatives connecting to an object antecedent. That this - 'thou wilt do more ...' - is the correct interpretation is proven by the Latin context quoted above.

\section{Validity of a rule excluding de-adjectival adverbs from fronting}

A few glosses superficially give the impression that in them, a de-adjectival adverb is clefted, and they now need to be addressed individually.
(14) $b a$ infortgidiu
$7 \quad b a$
hitemul
$\mathrm{COP}_{\text {3SG.PRET }}$
dugnith
the $_{\text {DAT.SG.NEUT }}=$ covert $_{\text {DAT.SG.NEUT }}$
and $\mathrm{COP}_{\text {3SG.PRET }}$
in= darkness $_{\text {DAT }}$
$\mathrm{PV} \cdot \mathrm{do}_{3 \mathrm{SG} . \mathrm{IMPF}} \mathrm{Saul}_{\mathrm{NOM}}$

'it was covertly and it was in darkness that Saul ... used to make ...' (Ml. 30 3 ) (for infortgidiu the manuscript has imfortgidiu)

If extracted and viewed in isolation, ba in [sic leg.] fortgidiu du-gnith would indeed constitute an adverbial cleft with a non-relative verb - for predicted ${ }^{\star} b a$ fortgide du-ngnith 'it was covert how he used to make' - but with the actual pairing of two diverse fronted elements, the continuous phrase hi temul du-gn ith is a normal adverbial cleft beginning with a prepositional phrase, and with such mixed fronting, the construction agrees most naturally with the second phrase hi temul, and the first phrase has been secondarily adapted to suit this syntactic context. For a similarly mixed fronting construction, compare Ml. $41^{\mathrm{d}} 9$ in (88) below.

(15) a. non dificulter ${ }^{\text {gl. } 21}$ eueniat $^{\text {gl. } 22}$ :
i. ní baindodaing
i.e. NEG $\mathrm{COP}_{\text {3SG.FUT }}$-the $_{\text {DAT.SG.NeUT }}=$ difficult $_{\text {DAT.SG.NEUT }}$
'i.e. it will not be with difficulty' $\left(\mathrm{Ml} .61^{\mathrm{a}} 21\right)$
b. dufórban
PV·happen ${ }_{3 \mathrm{SG} . \mathrm{PRES}}$
'it happens' (Ml. 61 ${ }^{\mathrm{a} 22}$; author’s trans.) 
Here one might expect that the connected Latin phrase non dificulter eveniat, 'it may/will not happen in a difficult way', were explained by an equally unified gloss, and in that case, in dodaing ${ }^{10}$ would be a fronted de-adjectival adverb, and the whole sentence would stand for predicted *níba dodaing du-forban (with nasalising relative). However, in the manuscript there is a clear space between indodaing and dufórban, with gloss $61^{\mathrm{a}} 21$ being almost exactly coextensive with the Latin phrase it explains and $61^{\mathrm{a}} 22$ only beginning over the second part of the $u$ of eueniat. Therefore, these are indeed separate glosses, and the adverb in dodaing renders dificulter in isolation, not as the first part of a cleft sentence. The same is even more clearly the case in:

multum.$i \quad$ is $\quad$ indil asferr
much i.e. $\mathrm{COP}_{\text {3SG.FUT }}$ the $_{\text {DAT.SG.NEUT }}=$ many $_{\text {DAT.SG.NEUT }} \mathrm{COP}_{\text {3SG.PRES.REL }}=$ better
iudeus quam gentilis
Judaeus than Gentilis
'multum i.e. it is greatly that Judaeus is better than Gentilis.' (Wb. 2a4)
gl. multum per omnem modum (Rom. 3:2) 'much in every way' (ESV)

As Thurneysen remarks on this isolated example, "the construction seems unIrish" (GOI $\S 383$ n.). While the combination of a fronted adverb with a relative verb could be justified as an incipient innovation (for which see GOI $\S 506$ ), the adverbial formation ind il itself (from il 'many, much', with ind as described in GOI §379) is entirely unparalleled. Instead, in order to express the concept of 'greatly' in this construction, *is mór as ferr might be expected - compare the material collection in section 4.2 below that does not include cases of the fronted positive mór, but, in many instances, the corresponding comparative mó 'more' instead. Rather than representing a natural Irish expression, then, ind il is best explained as a mechanical rendering of the Latin adverb multum, and to the extent that this is an artificial process, a correspondingly artificial translation 'muchly' may be proposed. This analysis ties in well with the more general observation that the unmarked Old Irish equivalent of what would be de-adjectival adverb formation in other languages is precisely the adjectival cleft under discussion, thus most clearly with comparatives and superlatives, for which direct adverbs like indluindiu (Ml. 32 ${ }^{\mathrm{d}} 1$, 'more angrily', glossing commotius) or inmáam (Wb. $1^{\mathrm{c}} 20$, 'most greatly', glossing primum), “are never

10 Griffith and Stifter (2013) take indodaing instead as containing the preposition in, but since dodaing is an adjective (albeit as such capable of substantivisation) and dificulter an adverb, direct equivalence of indodaing to the latter is more likely. 
found in a clause, but occur only as isolated glosses, the language of which is probably somewhat artificial" (GOI §382). Against this background, Mac Coisdealbha (1998: 156) suggests that:

such a situation obtained in part also for the non-comparative adverbial derived from the adjective, i.e. that it was expressed as a fronted element in the COP. EMPH. construction. ... This suspicion is strengthened by the general paucity of such ind-derivatives in the Würzburg period especially in complete clauses (as isolated translations of Latin adverbs they are more frequent).

In the present case, the only difference is that such a gloss on a Latin word in isolation has been embedded unchanged into the adjectival cleft structure. The exact same mixed construction is found, with an embedded Latin adverb, in:

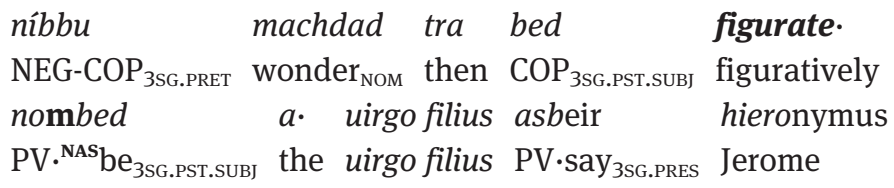

'and it were no wonder then that uirgo filius that Jerome speaks of, was figuratively' $\left(\text { Sg. } 62^{\mathrm{b}} 2\right)^{11}$

On the other hand, an ellipsis of the natural Irish construction, i.e. even without the following main verb, may be seen in:
(18)
etbadtreit
aimgabáil.
aris
huisse

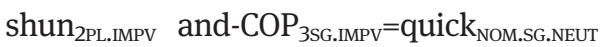
for- $\mathrm{COP}_{3 \mathrm{SG} \text {.PRES }}$
proper $_{\text {NOM.SG.FEM }}$
its=shunning NOM $_{\text {M }}$
'Shun ye and let it be quickly, for it is proper to shun it.' (Wb. 9 ${ }^{\mathrm{d}} 6$ )
(gl. fornicationem fugite)

for which the complete expression of the second part may be predicted as ${ }^{\star} b a d$ treit imme-n-imgabaid, 'let it be quick how you shun (it)' (while conceding that formally, treit could be either adjective or adverb).

\footnotetext{
11 The adverb figurate was likely obtained from the wider context of this passage (Thes. 2: $116.1=$ Hertz [1855-1858] 2009, 1: 145.20). It is used shortly before (at Thes. 2: $115.16=$ Hertz 2009, 1: 145.15).
} 


\title{
4 Old Irish corpus of adjectival cleft sentences ${ }^{12}$
}

\subsection{Fronted cían}

To begin with, a separate section is devoted to cían merely because in this construction, it is impossible to decide if cian is used with its adjectival value 'long' or in its equally common substantival function 'a long time' (compare also [89] in section 5.4 below).

\subsubsection{With overt spelling of nasalisation}

(19) $n \bar{\imath} b a$

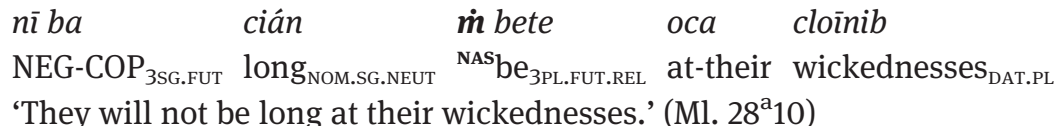

(20) nī $b a$ $\begin{array}{llll}\text { cian } & \text { mbias } & \text { in } & \text { pecthach } \\ \text { long }_{\text {NOM.SG.NEUT }} & \text { NAS }_{\text {be }} \text { 3SG.FUT.REL } & \text { the } & \text { NOM.SG.MASC } \\ \text { sinner }_{\text {NOM }}\end{array}$ NEG-COP
3SG.Fut
'The sinner will not abide long.'
Nom. $\left(\mathrm{Ml} .56^{\mathrm{C}} 22\right)$

(21)

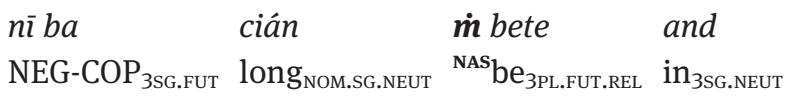
'They will not be there long' (Ml. 66 $\left.{ }^{\mathrm{d}} 14\right)$
(22) is
cián
$\dot{\boldsymbol{m}}$ bìs ánd
$\mathrm{COP}_{\text {3SG.PRES }}$ long $_{\text {NOM.SG.NEUT }}{ }^{\text {NAs }_{\text {be }}}$ 3SG.HAB $_{\text {is }}$ 3S.NEUT
'He is wont to be long therein.' (Ml. 100 $\left.{ }^{\mathrm{a}} 10\right)$

\subsubsection{Orthographically ${ }^{13}$ ambiguous regarding nasalisation}
(23) iscián
arfolmas
dún insin
$\mathrm{COP}_{\text {3SG.PRES }}=$ long $_{\text {NOM.SG.NEUT }}$
PV·undertake 3 SG.PRET.PASS
for $_{1 \mathrm{PL}}$ the $_{\text {NOM.SG }}=$ that $_{\mathrm{NOM}}$

\begin{abstract}
12 The following collection is intended to be complete for all sources edited in Thes., amounting in the main to the Würzburg, Milan and St. Gall Glosses.

13 In what follows, a distinction is made between orthographically ambiguous for cases in which a nasalisation, if present, would have been audible - such as in ar-folmas in (23), where $<\mathrm{f}>$ could represent either unlenited $f / \mathrm{f} /$, lenited $f / \varnothing /$ or nasalised $f / \mathrm{v} /-$, and phonologically ambiguous for cases in which a nasalisation could not have affected the stressed anlaut in pronunciation beyond non-lenition - such as the $r$ of do-réracht (24).
\end{abstract}


'It is long since that has been destined (has been imminent) for us. ${ }^{\text {,1 }}$ (Wb. 21 ${ }^{\mathrm{a}} 2$ )

For relative $a r$ - in (23) rather than ara-, see further under (90) below.

\subsubsection{Phonologically ambiguous regarding nasalisation}

(24) is

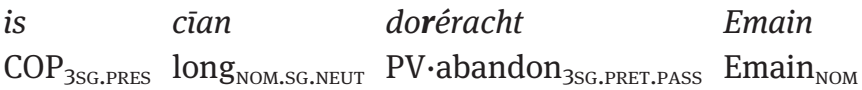

'Long since has Emain been forsaken.' (Thes. 2: 317.6 and 317.15 [Hymn ii])

\subsection{With comparative (and equative or superlative)}

According to Thurneysen (GOI $§ 383$ ), the adjectival cleft sentence "is the normal construction with adverbial forms of comparison" - albeit in a somewhat condensed expression for "replacing" or "corresponding to adverbial forms of comparison in other languages", since within the Irish construction itself, only the basic adjectival forms (i.e. those not overtly marked as adverbs) may be used. Compare similarly Mac Coisdealbha's (1998: 156) description: “The comparative and superlative attributive adjectives and corresponding adverbs must be formed predicatively with the copula." On account of this observation, a separate section is here dedicated to fronted degrees of comparison, and most of the extant examples involve a comparative.

Commenting on the basic 'is maith construction,' Sims-Williams (1984: 193) remarks further: "Note, however, that a nas. rel. clause is not regular in the similar constructions with a comparative (Ml. $22^{\mathrm{C}} 14=$ [102] below) or a superlative, in fer as deg do.cheil bile, 'the man who best hides a tree', Thurneysen 1946: 322 (cf. 681 n. 126) - on the Welsh construction which Thurneysen compares see P. Mac Cana, Celtica 7 (1966) 91-115.” The two examples adduced, however, are not parallel. While the second, construed superlative case illustrates a process of syntactic raising of the second relative clause to the level of the first - a process that will be addressed, with some real examples, in section 5.2 below $-\mathrm{Ml} .22^{\mathrm{C}} 14$ begins with air is mōu ru-icim les . . ' for it is more that I need . . .' and thus with a non-relative copula that does not deliver a context for raising. Instead, this is to

14 Following the translation in Kavanagh (2001: 103 s.v. ar-folmathar), vs. 'it is long since he destined (?) that to us' (Thes. 1: 631), but see GOI ( $\$ 708$ note) on the analogical spread of the third person singular passive preterite ending $-s$. 
be recognised as one of the few, innovatory exceptions to the nasalising relative rule in the adjectival cleft construction, see section 6.2.

Apart from such exceptions to be discussed further below, the attested cases involving fronted degrees of comparison are:

\subsubsection{With overt spelling of nasalisation}

(25)
a. isléir
dorigni
indalalestar
$\mathrm{COP}_{\text {3SG.PRES }}=$ careful $_{\text {NOM.SG.NEUT }}$
$\mathrm{PV} \cdot \mathrm{do}_{\mathrm{AUG} .3 \mathrm{SG} . \text { PRET }}$ one.of.two $=$ vessel $_{\mathrm{ACC}}$

'It is carefully he has made one of the two vessels.' (Wb. $\left.4^{\mathrm{c}} 32\right)(=[46 \mathrm{a}]$ below) followed by:

$\begin{array}{lll}\text { b. isdinnimu } & \text { dongní } & \text { alaill } \\ \mathrm{COP}_{\text {3SG.PRES }}=\text { careless }_{\text {COMP }} & \mathrm{PV}^{\text {NAS }} \mathrm{do}_{\text {3SG.PRES }} & \text { other }_{\mathrm{ACC}}\end{array}$

'It is more carelessly that he makes the other.' (Wb. $4^{\mathrm{c}} 33$ )

(26)

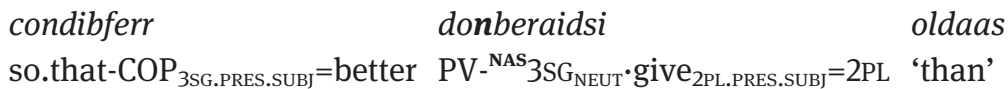

cách

anyone $_{\mathrm{NOM}}$

'that you may give it better than anyone (else)' (Wb. 16 ${ }^{\mathrm{c}} 9$ ) (donberaid for do-nd-beraid; see Thes. 2: 477)

(27) ismóa dongnísom oldaas

$\mathrm{COP}_{3 \mathrm{SG} . \mathrm{PRES}}=$ more $\mathrm{PV}-{ }^{\mathrm{NAS}} 3 \mathrm{SG}_{\mathrm{MASC}} \cdot \mathrm{do}_{3 \mathrm{SG} . \mathrm{PRES}}=3 \mathrm{SG}_{\mathrm{NEUT}}$ 'than'

dontlucham

PV- ${ }^{\text {NAS }} 3 \mathrm{SG}_{\mathrm{NEUT}} \cdot$ ask $_{1 \mathrm{PL} . \mathrm{PRES}}$

'He does it more than we ask it.' (Wb. 21 $\left.{ }^{\mathrm{d}} 9\right)$ (dongní . . . dontlucham = don [d]-gni ... don[d]-tlucham)

(28) Corrop

mōoassamōo et corrop

so.that-COP AUG.3SG.PRES.SUBj $_{\text {more=and }=\text { more and so.that-COP }}$ AUG.3SG.PRES.SUBJ

ferrassaferr donimdigi[d] desseirc dé

better=and=better PV. ${ }^{\text {NAs }}$ multiply 2 PL.PRES.SUBJ love $_{\mathrm{ACC}} \operatorname{God}_{\mathrm{GEN}}$

et comnessim

and neighbour $\mathrm{GEN}_{\mathrm{G}}$

'So that more and more, and so that better and better, ye may abound in love of God and of neighbour.' (Wb. $23^{\mathrm{b}} 1$ ) 
(29)
combad
mōu dē
donadbastae
molad
that-COP ${ }_{3 \text { SG.PST.SuBj }}$
more of 3SG.NEUT $_{\text {. }}$

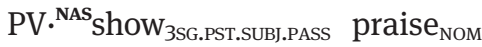

dǽ

trīachaingnimu

$\operatorname{God}_{\text {GEN }}$

through=his=good.deeds $\mathrm{Acc}_{\mathrm{Ac}}$

'that the praise of God might be more shewn (sic) forth through His good deeds' (Ml. 37 23 )

(30) ní lugu asnindet

läthar

innandūle

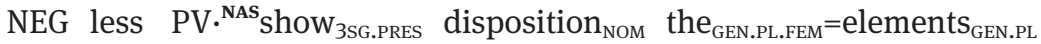

dodīa 7 nundfoilsigedar

indáas

to $=\mathrm{God}_{\mathrm{DAT}}$ and PV- ${ }^{\mathrm{NAS}} 3 \mathrm{SG}_{\mathrm{MASC}} \cdot$ manifest $_{3 \mathrm{SG} . \mathrm{PRES}}$ 'than'

'not less does the disposition of the elements set forth concerning God and manifest Him than ...' (Ml. 42 $\left.{ }^{\mathrm{b}} 18\right)$

(31) combad

mōu dè

nongabtis

inna

that-COP 3 SGG.PST.SuBj

more of ${ }_{3 \text { SG.NEUT }}$

$\mathrm{PV}^{\text {NAS }}{ }^{\text {take }}$ 3PL.PST.SUBJ

the ${ }_{\text {ACC.PL.NEUT }}$

forngaire

commands $_{\text {ACC.PL }}$

'that they might the more receive the commands' (Ml. 53' 13 )

(32) is

mōu dundrigēnsat

indaas

$\mathrm{COP}_{3 \mathrm{SG} . \text { PRES }}$ more PV- ${ }^{\mathrm{NAS}} 3 \mathrm{SG}_{\mathrm{NEUT}} \cdot \mathrm{do}_{\mathrm{AUG} .3 \mathrm{PL} . \text { PRET }}$ 'than'

sidrairlēcissiu

PV-3SG NEUT $_{\text {permit }}$ AUG.2SG.PEET $=2 \mathrm{SG}$

'They have done it more than Thou hast permitted it.' (Ml. $87^{\mathrm{a}} 8$ )

(33) cesu

meinciu aranecar...

arecar

although-COP ${ }_{3 S G . P R E S}$

danō cid sō

often ${ }_{\text {COMP }}$ PV $_{\text {REL }}{ }^{\text {NAS }}{ }_{\text {find }}$ SSG.PRES.PASS

PV·find ${ }_{3 S G . P R E S . P A S S}$

yet even this NOM $_{\text {NOM.SG.NEUT }}=$ rare $_{\text {DAT.SG.NEUT }}$

'although it is oftener found ..., yet even this is found rarely ...' (Sg. $\left.137^{\mathrm{b}} 2\right)$

(34) With equative:
islērithir
insō
nonguidimse
$\mathrm{COP}_{3 \mathrm{SG} . \mathrm{PRES}}=$ zealous $_{\mathrm{EQ}}$ the $\mathrm{ACC.SG}_{\mathrm{AC}}=$ this $_{\mathrm{ACC}} \quad \mathrm{PV}^{\mathrm{NAS}}$ beseech $_{1 \mathrm{SG} . \mathrm{PRES}}=1 \mathrm{SG}$
dīa nerutsu amal
$\operatorname{God}_{\mathrm{ACC}}$ for $_{2 \mathrm{SG}}=2 \mathrm{SG}$ as
'I beseech God for thee as urgently as . . .' (Wb. 27 $\left.{ }^{\mathrm{d}} 19\right)$ 
(35) With equative:

is soirbidir sin forndengatsom

$\mathrm{COP}_{\text {3SG.PRES }}$

inní easy $_{\mathrm{EQ}}$ that $_{\mathrm{ACC}} \mathrm{PV} \cdot{ }^{\mathrm{NAS}}$ oppress $_{3 \mathrm{PL} . \mathrm{PRES}}=3 \mathrm{PL}$

the $_{\text {ACC.SG.MASC }}=$ DEICT $_{\text {ACC }}$ be 3 SG.HAB.REL

'even so easily do they oppress him who is . . ' (Ml. $\left.75^{\mathrm{b}} 7\right)$

\subsubsection{Orthographically ambiguous regarding nasalisation}

\subsubsection{Relativity marked otherwise}

(36) $b a$ mmō immefolngitis brón damsa $\mathrm{COP}_{\text {3SG.PRET }}$ more $\mathrm{PV}_{\mathrm{REL}} \cdot$ cause $_{3 \mathrm{PL} . \mathrm{IMPF}}$ grief $_{\mathrm{ACC}}$ to $_{1 \mathrm{SG}=} 1 \mathrm{SG}$ '[They] used more to cause grief to me.' (Ml. $86^{\mathrm{d}} 6$ )

(37) ní lugu immefolngi sonartai do neuch NEG less $\mathrm{PV}_{\mathrm{REL}}$. cause $_{3 \mathrm{SG} . \mathrm{PRES}}$ strength $_{\mathrm{ACC}}$ to someone $_{\mathrm{DAT}}$ incotlud indaas the $_{\text {Nom.SG.MAsc }}=$ sleep $_{\text {Nom }}$ 'than' 'not less does sleep produce strength to a man than ...' (Ml. 135 13 13)

\subsubsection{Relativity otherwise unmarked}

(38)

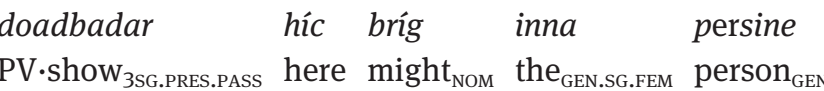
dodiccfa asmó de focíaltar

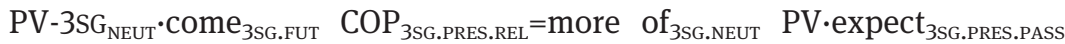
'Hic is shown the might of the Person that will so come, who is the more expected.' (Wb. 29c4) (but see also as [86] below)

(39) istraitiu adcotar fortacht dǽ

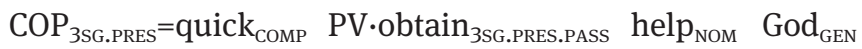
'the help of God is more quickly obtained . . .' (Ml. 92 $\left.{ }^{\mathrm{b}} 9\right)$

(40) combad mōu dē nocrete són

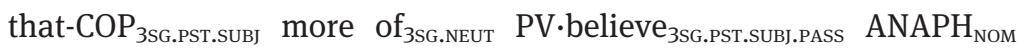
'that it might be the more believed ...' (Ml. 111 $\left.{ }^{\mathrm{d}} 4\right)$ 
(41) is dēniu adciam hūasūlib risīu

$\mathrm{COP}_{\text {3SG.PRES }}$ quick $_{\mathrm{COMP}} \mathrm{PV} \cdot \mathrm{see}_{1 \text { PL.PRES }}$ from=eyes DAT.PL $_{\text {before }}$

rocloammar infogur hūachlūasaib ut est

AUG.hear 1PL.PRES.SUBJ the $_{\text {ACC.SG.MASC }}=$ sound $_{\text {ACC }}$ with=ears DAT.PL $_{\text {that }}$

is toīsigiu adciam teilciud in bēla resīu

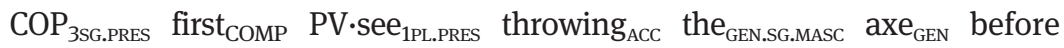
rocloammar a guth sidi

AUG.hear ${ }_{1 \text { PL.PRES.SUBJ }}$ its sound ACC ANAPH $_{\text {GEN }}$

'we see more quickly with the eyes before we hear the sound with the ears, ut est, we see the throwing of the axe before we hear the sound of it' (Ml. 112 ${ }^{\mathrm{b}} 12$ )

(42) nī mōa adcosnat

NEG more PV·strive 3 PL.PRES

'(they) do not strive more . . '’ (Thes. 2: 6.29 [Carlsruhe Augustine 12 ${ }^{\mathrm{d}} 1$ ])

(43) With superlative:

fib as deg ropri $[d]$ ched $^{15}$

as $\mathrm{COP}_{3 \mathrm{SG} \text {.PRES.REL }}$ best $\mathrm{AUG}$. preach ${ }_{\text {3SG.PRET.PASS }}$

'as it hath been preached best' (Wb. 23 ${ }^{\mathrm{a}} 3$ )

\title{
4.2.3 Phonologically ambiguous regarding nasalisation
}

\subsubsection{Relativity marked otherwise}
(44) is
mōo sluindes
pronomen persin quam
$\mathrm{COP}_{\text {3SG.PRES }}$ more signify 3SG.PRES.REL $_{\text {pronoun }}$ person $_{\mathrm{ACC}}$ than
aliae partes

\begin{abstract}
15 Strictly speaking, it has yet to be demonstrated if $<\mathrm{p}>$ in a nasalising context is ambiguous merely in orthography $(=/ \mathrm{b} /)$ or also phonologically $(=/ \mathrm{p} /)$. Caution in this regard is suggested by the behaviour, or perhaps merely representation, of $p$ under lenition, where it is, or appears, "sometimes lenited, sometimes not . . . Evidently the process, which had developed by analogy with the other stops, particularly with $b$ : $\beta$, had not yet become universal" (GOI § 231.5) for this originally foreign sound/letter. If the background to this is not merely graphical (cf. McManus 1983: 48, n. 63), but phonological, $p$ may have shown similar hesitation initially to undergo nasalisation (a possible early instance of the marking of nasalisation may be seen in the doubling in ippennit, 'in penance' (Thes. 2: 247.8 [Cambrai Homily])).
\end{abstract}


other parts

'The pronoun, more than the other parts of speech, signifies a person.' (Sg. 197 11$)$

\subsubsection{Relativity otherwise unmarked}

(45) amal as trummu forlūadi hisuidi

as $\mathrm{COP}_{\text {3SG.PRES.REL }}$ heavy COMP $_{\text {PV-Sway }} \mathrm{PSG.PRES}$ in=ANAPH $\mathrm{A}_{\mathrm{DAT}}$ 'as it sways more heavily therein' (Ml. 79 $\left.{ }^{\mathrm{b}} 5\right)$

(46)
a. isléir
dorigni
indalalestar
$\mathrm{COP}_{3 \text { SG.PRES }}=$ careful $_{\text {NOM.SG.NEUT }}$
$\mathrm{PV} \cdot \mathrm{do}_{\mathrm{AUG} .3 \mathrm{SG} . \mathrm{PRET}}$
one.of.two= vessel $_{\mathrm{ACC}}$

'It is carefully he has made one of the two vessels.' (Wb. $4^{\mathrm{c}} 32$ )

(followed by [25b], repeated here as [46b])

b. isdínnimu

dongní

alaill

$\mathrm{COP}_{\text {3SG.PRES }}=$ careless $_{\text {COMP }} \mathrm{PV} \cdot{ }^{\mathrm{NAS}} \mathrm{do}_{3 \mathrm{SG} . \text { PRES }}$ other ${ }_{\mathrm{ACC}}$

'It is more carelessly that he makes the other.' (Wb. $4^{\mathrm{c}} 33$ )

\subsection{With positive adjective}

\subsubsection{With overt spelling of nasalisation}

(47) $n \bar{b} b u$

$$
\text { degming }
$$

donet[h]adsom ${ }^{16}$

achorp

NEG-COP ${ }_{\text {3SG.PRET }}$ difficult $_{\text {NOM.SG.NEUT }}$

$\mathrm{PV} \cdot{ }^{\text {NAs }}$ gO $_{\text {3SG.PST.SUBJ }}=3 \mathrm{SG}_{\mathrm{MASC}}$

his $=$ body $_{\mathrm{ACC}}$

fadesin issuidiu

own in= ANAPH $_{\text {DAT }}$

'It was not difficult for him to go to his own body then.' (Wb. 13 ${ }^{\mathrm{d}} 20$ )

(48)
nīcumung
donindnagar
arforcital
dúib
$\mathrm{NEG}=$ straight $_{\text {NOM.SG.NEUT }}$
PV. ${ }^{\text {NAS }}$ bestow 3 SG.PRES.PASS
our=teaching NOM $_{2 \mathrm{PL}}$

'Not straitly [sic Thes.] is it that our teaching is given to you.' (Wb. 16 ${ }^{\mathrm{a}} 11$ )

\footnotetext{
16 Assigning this form to do-etha 'goes to, visits, approaches'. On the other hand, Thes. 1: 726 (addendum 588) reports "MS. donecadsom ('the he should see'), Chroust," i.e. from do-éccai 'looks at, beholds, sees.' Finally, Kavanagh (2001: 348) takes the lead from Pedersen (1909-1913, 2: 514) in positing a verb do-éta 'clothes' (albeit intended by Pedersen implicitly as subj. only), i.e. 'that he should clothe his own body therein' (cf. induere in the Latin context). The principal point in the present context, the relative nasalisation, remains unaffected.
} 
(49) nībrónach

donintarrái

$\mathrm{NEG}=\operatorname{sad}_{\text {NOM.SG.NEUT }}$ PV ${ }^{\text {NAS }}{ }^{\text {return }}$ AUG.3SG.PRET

'It is not sadly ${ }^{17}$ that he has returned.' (Wb. 16 ${ }^{\mathrm{b}} 18$ )

(50) nība

$$
\text { úaithed dondriga }
$$

NEG-COP 3 SGG.FUT few $_{\text {NOM.SG.NEUT }}$ PV- ${ }^{\text {NAs }}$ 3SG $_{\text {NEUT }} \cdot$ Come $_{3 \text { SG.FUT }}$

'It will not be with a few ${ }^{18}$ that he will come.' (Wb. 25 ${ }^{\mathrm{a}} 38$ )

(51) iseícrīchnichthe

\section{donindnigsom}

$\mathrm{COP}_{\text {3SG.PRES }}=$ unlimited $_{\text {NOM.SG.NEUT }} \mathrm{PV} \cdot{ }^{\text {NAS }}$ bestow ${ }_{3 \mathrm{SG} . \mathrm{PRES}}=3 \mathrm{SG}_{\mathrm{MASC}}$

adagmóini

his=benefits ACC.PL $_{\text {. }}$

'It is unlimitedly that He bestows His benefits,' (Wb. 28 ${ }^{\mathrm{a}} 17$ )

(52) arndip

maith

so.that-COP 3 3SG.PRES.suBj good $_{\text {NOM.SG.NEUT }}$

'that he care well for his household' (Wb. 28 $\left.{ }^{\mathrm{b}} 32\right)$

(53) $\operatorname{mad}$

$$
\text { ain }[m] \text { netach fondamtar }
$$

inna

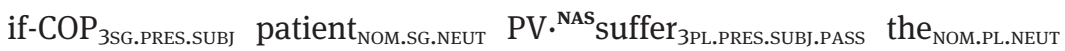
imneda inbetha frecndairc

troubles $_{\text {NOM.PL }}$ the $_{\text {GEN.SG.MASC }}=$ world $_{\text {GEN }}$ present $_{\text {GEN }}$

'if the troubles of the present world be borne patiently' (Ml. 46 $\left.{ }^{\mathrm{d}} 6\right)$

(54) airis

menic

dondecmaing,

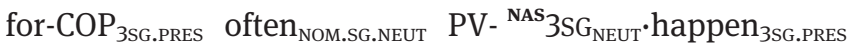

'For it often happens thus.' (Ml. 54 ${ }^{\mathrm{a}} 7$ )
amal as
trait
forndiuclannar
ade
as COP $_{\text {3SG.PRES.REL }}$ quick $_{\text {NOM.SG.NEUT }}$ PV. ${ }^{\text {NAS }}$ devour $_{\text {3SG.PRES.PASS }}$
ANAPH 'as it is quickly devoured' (Ml. $\left.104^{\mathrm{b}} 5\right)$

\footnotetext{
17 The interpretation as 'sadly' (implying the literal connection 'sad how'), rather than 'sad' (literally 'sad that'; see section 2.2), is confirmed by the Latin context: abundantius magis gauisi sumus super gaudio Titi, quia refectus est spiritus eius ab omnibus uobis (2 Cor. 7:13), 'we rejoiced still more at the joy of Titus, because his spirit has been refreshed by you all' (ESV). 18 Greene (1971) has shown that the DIL entry 1 úathad/óthad/úaithed is generally and originally an adjective meaning 'few'.
} 
(56) is dian immamberat acossa ind $\mathrm{COP}_{\text {3SG.PRES }}$ swift $_{\text {NOM.SG.NEUT }} \mathrm{PV}_{\text {REL }}{ }^{\text {NAS }}$ ply $_{\text {3PL.PRES }}$ their=feet $\mathrm{ACC} . \mathrm{PL}$ at the figi weaving ${ }_{\mathrm{DAT}}$ 'they ply their feet swiftly in the weaving.' (Ml. 111 $\left.{ }^{\mathrm{b}} 17\right)$

(57) coru[p]léir dungné nech that-COP AUG.3SG.PRES.SUBJ $=$ careful $_{\text {NOM.SG.NeUt }} \mathrm{PV} \cdot{ }^{\text {NAS }}$ do $_{3 \text { SG.PRES.Subj }}$ someone $_{\text {NOM }}$ inpreceupt the $_{\text {ACc.SG.MASC }}=$ teaching $_{\text {ACC }}$ 'that each one may diligently do the teaching' (Ml. 129 1 )

(58) issain donadbantar sensibus

$\mathrm{COP}_{\text {3SG.PRES }}=$ different $_{\text {NOM.SG.NEUT }} \mathrm{PV} \cdot{ }^{\text {NAS }}$ Show $_{\text {3SG.PRES.PASS }}$ sensibus 'Differently is it shown sensibus.' (Thes. 2: 4.32-33 [Carlsruhe Augustine $\left.\left.10^{\mathrm{a}} 2\right]\right)$

(59) is

$\begin{array}{llll}\text { is } & \text { bec } & \text { nand } & \text { sinunn } \\ \mathrm{COP}_{\text {3SG.PRES }} & \text { little }_{\mathrm{NOM} . \mathrm{SG} . \mathrm{NEUT}} & \mathrm{NEG}_{\mathrm{SUB}^{-}}{ }^{\mathrm{NAs}} \mathrm{COP}_{\text {3SG.PRES }} & \text { same }_{\text {NOM.SG.NEUT }} \\ \text { andéde } & \text { nísĩu } & \\ \text { the }_{\mathrm{NOM} . \mathrm{SG} . \mathrm{NEUT}}=\text { two }_{\mathrm{NOM}} & \text { DEICT this }\end{array}$

the $_{\text {NOM.SG.NeUT }}=$ two $_{\text {NOM }}$ DEICT_this

'These two (explanations) are nearly the same.' (Sg. 76 3 3)

(60) isáilgen

doneprinn

$\mathrm{COP}_{\text {3SG.PRES }}=$ gentle $_{\text {NOM.SG.NEUT }}$ PV ${ }^{\text {NAs }}$ flow $_{\text {3SG.PRES }}$

'Gently it flows.' (Sg. 145ª

\subsubsection{Orthographically ambiguous regarding nasalisation}

(61) is
$\mathrm{COP}_{\text {3SG.PRES }}$ firm $_{\text {NOM.SG.NEUT }}$
atreba ní clantar
plant $_{\text {3SG.PRES.PASS.REL }}$
'What is planted dwells firmly.' (Ml. 63 $\left.{ }^{\mathrm{b}} 9\right)$

(62)
combad
ellam
nocomallaitis aní
that-COP ${ }_{\text {3SG.PST.SUBj }}$
speedy $_{\text {NOM.SG.NEUT }}$
PV.fulfil ${ }_{\text {3SG.PST.SuBj }}$ the ACC.SG.NEUT $=$ DEICT 
asrochoīlset

PV·determine AUG.3PL.PRET $_{\text {. }}$

'that they should speedily fulfil what they had determined' (Ml. 95 2 2)

(63) commixtum interpretatur i. cummascdae adfét

commixtum interpretatur i.e. mixed $_{\text {NOM.SG.NEUT }}$ PV·tell ${ }_{3 \text { SS.PRES }}$

in salmso di būaid innam

the $_{\text {NOM.SG.MASC }}=$ psalm $_{\text {NOM }}=$ PROX of victory ${ }_{\text {DAT }}$ the GEN.PL.MASC

babelóndae

Babylonians $_{\text {GEN.PL.MASC }}$

'i.e. this psalm speaks mixedly of the victory over the Babylonians.'

(Ml. 115 ${ }^{\mathrm{d}} 9$ )

\subsubsection{Phonologically ambiguous regarding nasalisation}

\subsubsection{Relativity marked otherwise}

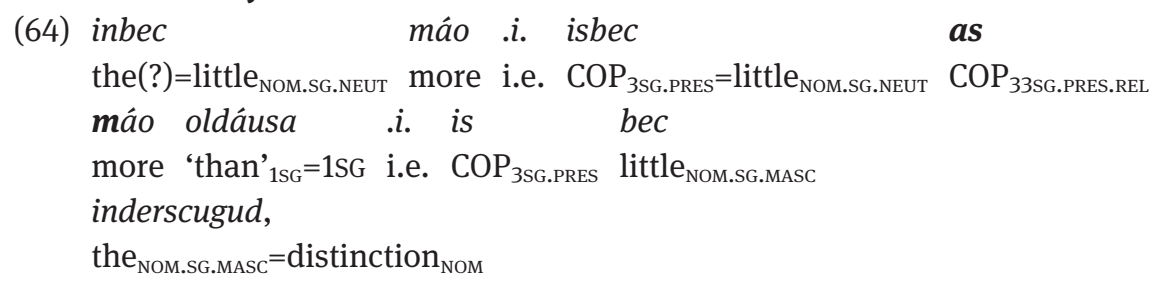

'A little greater i.e. she is a little greater than I, i.e. the distinction is small.' (Sg. 45 15 )

(gl. paruo maior ${ }^{19}$ in paruo maior quam ego, 'a little greater than I.')

In view of the standard teaching on the formation of adverbs, ${ }^{20}$ Stokes and Strachan (Thes. 2: 99 n. c) wonder if for inbec "leg. inbiuc, or is becmáo a compound?". Neither the emendation, however, nor the assumption of an unparalleled compound are necessary, if one (i) derives the element in $(d)$ in adverbs not from the article, but from the preposition/preverb ind(-), ${ }^{21}$ and (ii) takes account of the

19 In the manuscript, the gloss begins above the $p$ of paruo and continues beyond maior into the empty space to the right of the column, whereas quam ego begins the following line.

20 "To form an adverb, the dat. sg. of the adjective preceded by the article - or at all events by a word identical in form with the article - is generally used” (GOI §379); cf. Mac Coisdealbha (1998: 155-157).

21 As considered in GOI (§ 379 note) and first argued by Morris Jones (1913: 439), cf. further Vendryes (1928), including his comment on the related Old Latin preposition endo that "elle 
fact that the dative form is not found with all cases of this formation. ${ }^{22}$ Examples of what instead must be the accusative are listed in GOI (§379) itself, such as:

(65) a. indoll 'amply' (Sg. 220ª; author's trans.), gl. ultra 'beyond', rather than *ind ull-for the expected raised vowel cf. the comparative huilliu, e.g. Sg. $70^{\mathrm{a}} 6$;

b. inmade, inmadæ 'in vain' (Wb. $\left.19^{\mathrm{b}} 10,19^{\mathrm{d}} 16\right)$ gl. sine causa 'without cause'-contrast the dative mudu (Wb. 16 $\left.{ }^{\mathrm{d}} 4\right)$;

c. ind immdae 'abundantly' (Sg. 26 $\left.{ }^{\mathrm{a}} 5\right)$, gl. examosin ${ }^{23}$ - "beside normal" (GOI § 379) indimdu (Ml. 35 5 ), gl. passim 'in every part'.

For forms like ind oll and ind immdae, the article is clearly ruled out, since its accusative singular (masculine/feminine) form would be in $n-$. Instead, the possibility of accusatival/directional adverbs (including with prepositions taking the accusative), beside datival ones, is further supported by the alternative formation with co 'to' (GOI §381) - consider further the English alternative between 'in a certain way' and 'to a certain extent'. Accordingly, the preposition in $(d)$ could take either the dative or the accusative, ${ }^{24}$ and in bec is to be taken as a regularly formed adverb - as an alternative to datival inbiucc 'in small measure' (e.g. Sg. 39²5) - glossing paruo in isolation (followed by máo for maior), before the entire Latin phrase paruo maior quam ego is rendered in more natural Old Irish by the adjectival cleft sentence is bec as máo oldáu-sa.

\subsubsection{Relativity otherwise unmarked}
(66) nírbu
faás
foruigéni
NEG-COP ${ }_{\text {AUG.3SG.PRET }}$ empty NOM.SG.NEUT $_{\text {PI }}$
$\mathrm{PV} \cdot$ serve $_{\mathrm{AUG} .3 \mathrm{SG} . \mathrm{PRET}}$
'Not void has been his service.' (Wb. 13 ${ }^{\mathrm{b}} 7$ )
gl. et gratia eius in me uacua non fuit (1 Cor. 15:10) 'And his grace toward me was not in vain.' (ESV)

\footnotetext{
devait admettre après elle le datif aussi bien que l'accusatif [it must have taken after it the dative as well as the accusative]" (Vendryes 1928: 78) and Lambert (1995: 174-175), the latter assigning the preposition ind the meaning 'en direction de, contre [towards, against]'.

22 A fact that is not mentioned by Thurneysen in GOI despite being reflected in his collection of examples, or by Lambert, while some cases were at least pointed out in Thurneysen (1909: $\S 378)$.

23 Recte examosim (Sg. 26 ${ }^{\mathrm{a}}$ ), for examussim 'according to a rule or measure, exactly, regularly, perfectly' (Glare [1968-1982] 2012: s.v. examussim). The gloss, therefore, is "probably guesswork, concluded from the context” (Hofman 1996, 1.2: 115).
}

24 Like its allomorph $i$ n- etc.; see GOI (§ 842). 
(67) isdian

$$
\text { dorrēractid }
$$

maâm

$\mathrm{COP}_{3 \text { SG.PRES }}=$ swift $_{\text {NOM.SG.NEUT }} \mathrm{PV} \cdot$ abandon $_{\text {AUG.2PL.PRET }}$ yoke ACC $_{\text {acc }}$ indsoscéli

the $_{\text {GEN.SG.NEUT }}=$ gospel $_{\text {GEN }}$

'It is swiftly that ye have abandoned the yoke of the gospel.' (Wb. 18 ${ }^{\mathrm{c}} 6$ )

(68) isimde

$$
\text { dorrindnacht dún }
$$

$\mathrm{COP}_{\text {3SG.PRES }}=$ abundant $_{\text {NOM.SG.NEUT }} \mathrm{PV} \cdot$ bestow $_{\text {AUG.3SG.PRET.PASS }}$ to ${ }_{1 \mathrm{PL}}$

'Abundantly it has been bestowed upon us' (Wb. 20 d 15$)$

(69) is

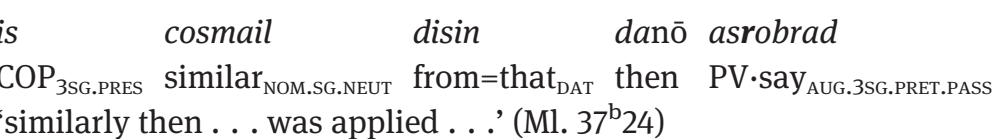

(70) nant

maith

sroìtatar

$\mathrm{NEG}_{\mathrm{SUB}}-\mathrm{COP}_{\text {3SG.PRES }}$

$\operatorname{good}_{\text {NOM.SG.NEUT }}$

PV·guard AUG.3PL.PRET $_{\text {. }}$

arríg

their= king $_{\text {ACC }}$

'that they did not guard their King well' (Ml. $\left.55^{\mathrm{c}} 1\right)$

As an interim summary, it can be stated that all examples of the adjectival cleft construction adduced so far - which constitute the vast majority - either show a clearly marked nasalising relative verb or are orthographically/phonologically compatible with it.

\section{Apparent exceptions to the nasalising relative construction}

\subsection{Non-class $C$ infixed pronouns}

(71) ni maith $\quad$ domrignis
NEG $\operatorname{good}_{\text {NOM.SG.NEUT }}$ PV-1SG·do ${ }_{\text {AUG.2SG.PRET }}$
'Not well hast thou made me.' (Wb. 4 $\left.^{\mathrm{c}} 27\right)$ 
(72) nipadro(mór) $)^{25}$

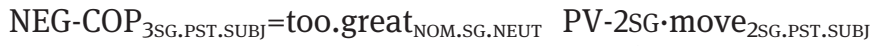

'Thou shouldst not boast overmuch.' (Wb. $5^{\mathrm{b}} 32$ )
(73) menicc

often $_{\text {NOM.SG.NEUT }}$ dosnicfed

\section{atchith} PV-3SG ${ }_{\mathrm{NEUT}}{ }^{\mathrm{LEN}}$ See $_{3 \mathrm{SG} . \mathrm{IMPF}}$ hi fisib /

PV-3SG $\mathrm{FEM}{ }^{\mathrm{NAS}} \mathrm{Come}_{3 \mathrm{SG} . \mathrm{CND}}$ again

'Often he used to see in visions that he should come to it again.' (Thes. 2: 312.4 [Hymn ii])

In ascertaining if, in the adjectival cleft construction, a nasalising relative main verb is compulsory (as indicated in GOI $\S \S 383$, 505), the first observation concerning the examples above is that no nasalisation, or indeed relativity, is marked in them, and dom-rignis and not-boccth ${ }^{26}$ could serve unchanged to introduce a main clause, such as described, for instance, in GOI (§505) as an alternative to most other nasalising relative constructions. Accordingly, Pedersen (1899: 414) remarks on (71) that "das . . . zu erwartende relative $n$ fehlt that . . for which the expected relative $n$ is missing]", while Mac Coisdealbha (1998: 155) similarly points to the fact that (72) "do[es] not show nasalization" as an argument against the presence of a nasalising relative. Moreover, Isaac in Mac Coisdealbha (1998: 257) compares (72) directly with (100) below:

As for [these] two [examples], the fact is that the opportunity for nasalization is there. $5 \mathrm{~b} 32[=(72)]$ could have shown nasalization if it had contained the Class C infixed

25 Vs. "nípadruo••, worauf zwei buchstaben etwa abgerieben wurden, Chroust [nípadruo••, after which about two letters have been erased]" (Thes. 1: 725 [addendum 528]). Previously, Strachan (1899: 42) had suggested reading nipa[d] dron . . . . The images both in the facsimile (Stern 1910) and online (http://vb.uni-wuerzburg.de/ub/mpthf12/pages/mpthf12/9.html) seem compatible with reading nipadro (with a gap between $d$ and $r$ ) and at least one more minim (such as the beginning of an $n$ or $m$ ). The anonymous reader cautions that there is hardly enough space for ro[mór] in the manuscript and suggests that the intended adverb may be rom 'early, too soon', and furthermore that rather than taking boccaid plus reflexive infixed pronoun with the unparalleled meaning 'boasts', one of the more common meanings 'softens' or 'moves' (DIL) may be intended - thus implying, for instance, a literal 'that it not be too soon that you move yourself'.

26 Since (73) is not preserved in a contemporary Old Irish manuscript, the infixed pronoun in at-chith can be taken either as expressing Old Irish prolepsis (cf. GOI § 421) or as showing (in this case scribal) Middle Irish petrification of neuter pronouns (cf. McCone 1997: 172-173). In the latter case, the Old Irish original might have had non-proleptic * $a d$-cith, with $c^{-}=/ \mathrm{g} / \mathrm{mark}$ ing the expected nasalising relative. 
pronoun: *nípadromór nondatbocctha. But it is perfectly regular for Class A, which cannot realize nasalization, to appear in this position, GOI §413.2. 13a29 [= (100)] could have read *badféal et badfedte dongneid cachréit. But it does not. In both cases, the opportunity to nasalize was not taken. Thurneysen's rule can, then, at best be taken as a facultative formal strategy. ${ }^{27}$

Pace Isaac, however, his two examples represent two different types of exception. In bad fedte do-gneid, the opportunity to nasalise is indeed there and was not taken, meaning that this and some similar cases constitute real exceptions to the predicted nasalising relative construction and will be addressed as such in section 6. In cases like (72), on the other hand, that opportunity would have had to be created first by switching the infixed pronoun from class A to class C, and it is the opportunity of marking the relative by using class $C$ that was not taken, not that of applying nasalisation, which is formally impossible with class A. In order to assess the latter type of exception, therefore, it will be necessary first of all to review the use of infixed pronouns in relative clauses.

Thurneysen (GOI § 413.2) observes that in relative verbs, class C "regularly replaces the pronouns of class $\mathrm{A}$ in the third person only; but it is frequently (though not invariably) used instead of the first and second persons of $\mathrm{A}$ and all the forms of B". From this it follows - as is in fact conceded by Isaac himself above - that in a relative context, a form with a class $\mathrm{A}^{28}$ or $\mathrm{B}$ pronoun is to be considered just as relative in status as one with class $\mathrm{C}$, albeit without any overt marker of relativisation, which can only be expressed - by lenition or nasalisation - on the - $d$ - of a class $\mathrm{C}$ pronoun (for more discussion on some of these points, see García-Castillero's contribution to this volume). ${ }^{29}$ To test this, one needs of course to rely on constructions that are unambiguous in requiring a relative verbal form, and the clearest, and entirely undisputed, case in this

27 The same direct comparison is implicit in Ó hUiginn's (1986: 58) more complete collection of formally deviant examples from the glosses, comprising, on the one hand, (71) and (72), as well as, on the other, arachrin in (96) and dogneid in (100) and some others of the same nature (on which see further sections 6.1 and 6.2 below), leading him to summarise that "it would be more accurate to see the use of the nasalizing relative in such cases as more of a normal custom than a fast rule". Note, however, that while Ó hUiginn (1986) classifies verbs with nonClass C pronouns as non-relative throughout his collections (e.g. p. 44), his reference (p. 67) to "instances of a class A inf. pron. . . . being retained in a rel. clause" implies - in my view correctly - that a non-class $\mathrm{C}$ pronoun alone cannot serve to prove that the verb is non-relative.

28 Compare Strachan (1903a: 67, n. 3): "It does not seem to have been noted that, when the short forms of the infixed pronouns of the first and second persons appear in relative use, relative $-n$ - is not inserted before them."

29 While lenition of $d$ cannot be marked within the Old Irish orthographical system, its presence can be deduced from the parallel relative nasalisation yielding written -nd- (GOI §504 [b]). 
regard is the leniting relative following a subject antecedent. The first two examples below, (74) and (75), illustrate that while a class $C$ pronoun is admissible in order to express both relativity and lenition (on the $d$ - of -dam-), it is not compulsory for this person (first singular), and class A - $m$ - may be used as well, without affecting the underlying syntax:

(74) indí

fodamsegatsa

the $_{\text {NOM.PL.MASC }}=$ DEICT PV-1SG afflict $_{\text {3PL.PRES }}=1$ SG

'those who afflict me' (Ml. 33 ${ }^{\mathrm{a}} 19$; author's trans.)

(75) Isiress

crīst nombēoigedar

$\mathrm{COP}_{\text {3SG.PRES }}=$ faith $_{\mathrm{NOM}}$ Christ $_{\mathrm{GEN}}$ PV-1SG.vivify 3 3SG.PRES

'It is Christ's faith that quickens me.' (Wb. 19²0)

Example (75) is a subject-fronting cleft sentence with mandatory leniting relative connection, so it would not be useful to classify the verb nom-béoigedar 'which enlivens me' as non-relative merely because neither relativity nor lenition could be expressed or realised on the surface. Rather, this is a leniting relative clause in status, but without the possibility of relative marking or lenition because of the choice of the more unmarked class A for the infixed pronoun. Furthermore, (76) may serve to illustrate Thurneysen's rule that within class A, only non-third persons are admissible in relatives:

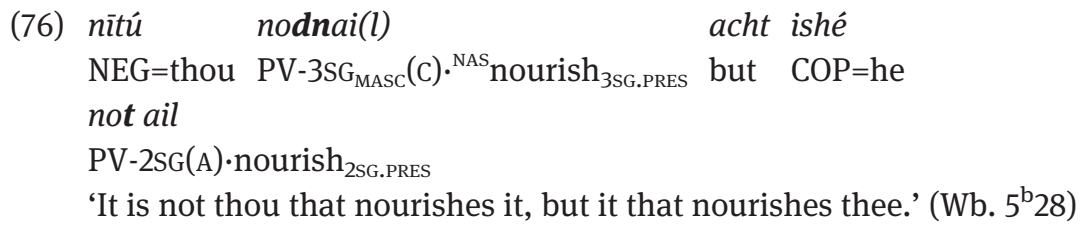

Again, both parts of this sentence are subject clefts, entailing mandatory leniting relatives, ${ }^{30}$ but the relative is marked only by and on the third person singular masculine class $\mathrm{C}$ pronoun $-d-n$ - in the first verb. This is not formally possible with the second person singular class A pronoun - $t$ - in the syntactically

30 "Altogether distinct from this is the use of a non-relative form in the second of two parallel relative clauses, a construction found in many other languages" (GOI $\S 505$ note), referring to amal as toīsegiu grián indáas laithe ${ }_{7}$ is laithe foilsigedar cech rét síc is toissigiu 'as the sun is prior to the day, and it is the day that makes clear every thing, so . . . is prior . . ' (Ml. 85 $\left.5^{\mathrm{b}} 11\right)$, which shows a pairing of two (underlying) relatives, not of two cleft sentences, each of which contains a relative. 
parallel second verb, but not-ail must nonetheless be classified functionally as a leniting relative, and not as a non-relative verb.

Similar considerations apply to the use of class B in relatives. ${ }^{31}$ For this, it is instructive to begin by comparing the only other construction in which "a nasalizing relative clause can[not] be replaced by a formally independent (i.e. principal) clause" (GOI § 505), namely the figura etymologica connecting a verbal noun with its own verb via an adverbial nasalising relative (literally 'wherewith', 'by which'), as described in GOI (§ 499). Against McCone’s (1980: 23-24) objection, that some examples in $\mathrm{Wb}$. and Sg. show a leniting relative instead, ${ }^{32}$ Stüber (2010-2012: 235, 240) not only follows Ó hUiginn (1983: 123-124) in distinguishing three syntactic types of figura etymologica, ${ }^{33}$ but also demonstrates that the perceived exceptions are limited to the first two types, i.e. to object or subject-antecedent constructions that allow or indeed require a leniting relative also elsewhere. Among the strictly 'third-type', i.e. adverbial relative figurae etymologicae, ${ }^{34}$ Stüber (2010-2012: 252-254) observes merely two deviant cases:

$\begin{array}{llll}\text { frissan } & \text { ingraim } & \text { ataroigrainn } & \text { saul } \\ \text { to-the }_{\text {ACC.SG.NEUT }} & \text { persecution }_{\text {ACC }} & \text { PV-3PL(B).persecute } \\ \text { AUG.3SG.PRET } & \text { Saul }_{\text {NOM }}\end{array}$
'as to the persecution wherewith Saul persecuted them' (Ml. $30^{\mathrm{b}} 2$; emended reading by Griffith and Stifter 2014: 58-59)

(78)

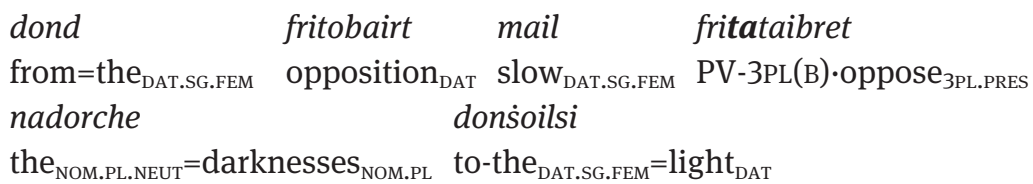

'from the slow opposition with which the darkness opposes itself to the light' (Sg. 183 3 )

31 Apart from preverbs ending in a dental such as ad-, where both ${ }^{\star} a ð$ - $\circlearrowright$ - with class $\mathrm{C}$ and * $a$ ठ- $d$ - with class B yield at- /ad/ through homorganic delenition; cf. massuthol atomaig, 'if it is desire that drives me' $\left(\mathrm{Wb} .10^{\mathrm{d}} 26\right.$ (ad-aig)).

32 See with further examples Ó hUiginn (1983: 123, n.2), and cf. Ó hUiginn (1986: 34).

33 "The first of these is that in which the antecedent acts as the grammatical subject of a passive verb . . . In the second type the antecedent functions as the object of an active transitive verb", while in the third type, "the antecedent verbal noun" is taken up by a "following rel. clause which already has a subject or object" (Ó hUiginn 1983: 124). The latter "tripartite type" (Ó hUiginn 1983: 124) alone necessarily figures the adverbial relative connection under consideration here.

34 Termed "intrumentalisch [instrumental]" by Stüber (2010-2012: 231, 245). 
Stüber (2010-2012: 253) considers “dass in diesen zwei Beispielen offenbar keine Relativsätze vorliegen [that these two examples apparently do not involve relative clauses]", but concedes the alternative that these are examples of "der seltene Fall [the rare case]" of a class B pronoun used in a relative clause, for which she adduces the following parallel:

$\begin{array}{ll}\text { (79) } i s h \bar{e} & \text { danō cotammidethar } \\ \mathrm{COP}_{\text {3SG.PRES }}=\text { he then } & \text { PV-3PL(B)·power } \\ \text { 3SG.PRES }\end{array}$

'It is He then that hath power over them.' $\left(\mathrm{Ml} .17^{\mathrm{b}} 2\right)$

All three of these examples clearly show a class B pronoun in a relative verb, contrast the same preverbs with class $C$, first in the same verb in-greinn as in (80), then in fris-gair (81) and finally in con-ocaib (82) - (80) and (82) feature nasalising relatives, (81) a leniting one:

(80) anindagreinnsiu

when- ${ }^{\mathrm{NAS}} \mathrm{PV}-{ }^{(\mathrm{NAS})} 3 \mathrm{PL}(\mathrm{C}) \cdot$ persecute $_{2 \mathrm{SG} . \mathrm{PRES}}=2 \mathrm{SG}$

'when Thou dost persecute them' (Ml. 36 ${ }^{\mathrm{d}} 2$ ) (for aninda manuscript has anunda)

(81) is $\quad \bar{\imath} \quad$ Bē Find friss doghair

$\mathrm{COP}_{3 \mathrm{SG} . \mathrm{PRES}}$ she Bé ${ }^{\mathrm{LEN}}$ Find $\mathrm{NOM}_{\mathrm{N}} \mathrm{PV}-3 \mathrm{SG}_{\mathrm{FEM}}(\mathrm{C}) \cdot{ }^{\mathrm{LEN}}$ correspond ${ }_{3 \mathrm{SG} . \mathrm{PRES}}$

'It is [the name] Bé Find that corresponds to her.' (Bergin and Best 1934-1938, 158, § 23; author’s trans.) $)^{35}$

(82) ancondammucbaitisse

when- ${ }^{\mathrm{NAS}} \mathrm{PV}-1 \mathrm{SG}(\mathrm{C}) \cdot$ exalt $_{3 \mathrm{PL} . \mathrm{IMPF}}=1 \mathrm{SG}$

'when they used to exalt me' (Ml. 39'11)

Compare further the following passage from an originally Old Irish text for the regular interchange in relatives between third persons of class $C$ in place of non-relative class A and unadapted class B:

35 On fris.dog(h)air, see also Thurneysen (1940: 28), who points out that the combination of preverbs in -s and a directly following $d$ - of a class $C$ pronoun in leniting relatives, i.e. as- $d$ and fris- $d$-, is not found in the glosses and is otherwise very rare. For $a s-n / \dot{n}-d$ - in nasalising relatives, see Ml. $31^{\mathrm{b}} 22,93^{\mathrm{d}} 14,114^{\mathrm{a}} 7,124^{\mathrm{d}} 7$. For further discussion of the fris- with class C pronouns, see García-Castillero's contribution to this volume. 
(83) Is $\begin{array}{llllll}\text { Is } & e & \text { dorósat } & \text { na } & \text { huili } & 7 \\ \text { COP }_{\text {3SG.PRES }} & \text { he } & \mathrm{PV} \cdot \text { create }_{\text {AUG.3SG.PRET }} & \text { the }_{\text {ACC.PL.NEUT }} & \text { all }_{\text {ACC.PL.NEUT }} & \text { and }\end{array}$ rodacruthaigestar 7 fodaloing ó nirt AUG-3PL(C)·form 3SG.PRET $_{\text {and PV-3PL(C).sustain }}$ 3SG.PRES by might DAT $_{\text {DA }}$ a chumachtai. Iss é nodaail 7 his power $_{\text {GEN }} \quad \mathrm{COP}_{3 \mathrm{SG} . \mathrm{PRES}}$ he PV-3PL(C).nourish ${ }_{3 \mathrm{SG} . \mathrm{PRES}}$ and $\begin{array}{llll}\text { cotaói } & 7 & \text { nodafáiltigedar } & 7\end{array}$

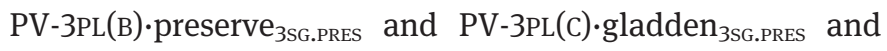
$\begin{array}{llll}\text { nodasorchaigedar } & 7 & \text { cotamidethar } & 7\end{array}$ PV-3PL(C).illuminate 3 SG.PRES and PV-3PL(B)·rule 3 SG.PRES and dodaraithchiúir $\quad 7$ atanúigedar na PV-3PL(C)·redeem ${ }_{\text {AUG.3SG.PRET }}$ and PV-3PL(B)·renew SG.PRES $_{\text {the }}$ ACC.PL.NEUT huili, all $_{\text {ACC.PL.NEUT }}$

'He it is who has created all things, and who has formed them and who sustains them by the might of his power. He it is who nourishes and preserves and gladdens and defective marking of relative lenition has redeemed and renews all things.' (Strachan 1907: 3, 8)

Like in (76), this is a (longer) sequence of subject clefts, entailing mandatory leniting relatives, but again the lenition can be realised on the surface only with the class $\mathrm{C}$ pronouns, not with the three cases of class $\mathrm{B}$. That, however, does not mean that these three verbs in the chain are not functionally relative and could serve to define an exception to the mandatory nature of a leniting relative after a subject antecedent.

For the adjectival cleft under consideration, then, examples (71) to (73), by not offering the surface option of marking nasalising relativity because of their choice of the more unmarked infixed pronoun classes A and B, respectively, cannot therefore, it is true, serve as proof of the mandatory status of a nasalising relative in this construction. Neither, however, can they be cited as exceptions to it, since in form they are ambiguous as to whether they are main-clause verbs or functionally nasalising relative ones without overt relative marking.

36 Given here in Strachan's Old Irish restoration based on two manuscripts, but one manuscript copy agrees in all relevant detail concerning the infixed pronouns (Strachan 1907: 2), while in the second copy, only two of the pronouns have been corruptly transmitted (rocruthaigestar, donail, see Meyer 1903: 242). 


\title{
5.2 Syntactic raising due to embedding
}

\author{
(84) hiris innaní as deg \\ faith $_{\text {ACC }}$ the GEN.PL.MASC $={ }^{\mathrm{NAS}} \mathrm{DEICT}_{\text {GEN.PL. }} \mathrm{COP}_{3 \mathrm{SG} . \text { PRES.REL }}$ best \\ rochreitset hicrīst \\ AUG $^{\text {.EN }}{ }^{\text {believe }}$ 3PL.PRET $_{\text {in }}=$ Christ $_{\text {DAT }}$ \\ 'faith of those who have best believed in Christ' (Wb. 31 $\left.{ }^{\mathrm{a}} 6\right)$
}

On this case, Pedersen (1899: 351) remarks: "rochreitset ist selbstverständlich mit innaní zu verbinden, as deg als adverbiale bestimmung zu rochreitset aufzufassen [Needless to say, rochreitset is to be construed with innani and as deg to be taken as qualifying rochreitset adverbially].” And Thurneysen comments:

An amalgamation of relative constructions . . is . . f found when a superlative is taken
out of the relative clause and placed in front of it in periphrasis with a relative form of the
copula . . . Here, however, against the rule in $\S 498$, the second relative clause remains a
leniting one.
(GOI $\S 508$ ) and:

Here it is more probable that innaní is felt as the antecedent both of as deg and ro.chreitset (GOI 681, n. 126.)

As for the superlative "taken out of" the relative clause, this positioning of degrees of adjectival comparison is actually the only option to express them in adverbial function, as described above (section 4.2). But what is remarkable here is the use of a leniting relative in ro chreitset, since the basic sentence with a non-relative copula would be expected to be *is deg ro creitset, literally 'it is best how they have believed', with a nasalising relative. After embedding this clause into the context of syntactic dependency from inna $n-i$ ' 'of those,' however, ro creitset governed by deg was 'raised' to connect directly to the superordinate inna $n$ - $i$ to yield 'of those who have believed', with the normal leniting relative after a subject antecedent. ${ }^{37}$ What makes this example particularly valuable is the retained singular as after the plural inna $n$-í, thereby showing the "amalgamation" referred to in GOI - rather than a full adaptation to *ata deg ro chreitset, literally 'who are best who have believed' (cf. [89] below). A syntactically less complex case also adduced in GOI ( $§ 508)$ is:

37 Thurneysen's “remains” (GOI § 508) is accordingly to be understood as denoting the transferral of the leniting relative from the now syntactically parallel $a$ s before it. 
(85)
asmaam
rosंechestar
arsidetaid
$\mathrm{COP}_{3 \mathrm{SG} . \mathrm{PRES} . \mathrm{REL}}=$ most $\mathrm{AUG} \cdot{ }^{\mathrm{LEN}}$ follow $_{3 \mathrm{SG} . \mathrm{PRET}}$ antiquity ${ }_{\mathrm{ACC}}$
'who has most followed antiquity' (Sg. 208 15 )

This example again adapts non-relative ${ }^{\text {is }}$ maam ro sechestar. Furthermore, Elliott Lash has suggested to me that what was listed above as (38), assuming an orthographically ambiguous nasalising relative, could instead be understood as raised, with defective marking of relative lenition, which is why it is here restated with new numbering:

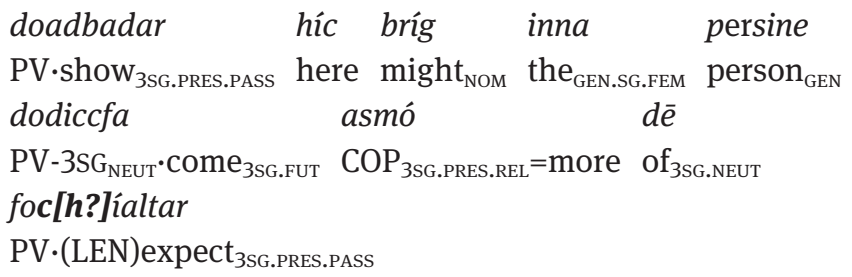

'Hic is shown the might of the Person that will so come, who is the more expected.' (Wb. 294)

Compare finally the Modern Irish reinterpretation of this pattern, described as “double relative construction" by Ó Nolan (1920: 114-116):

(87) Is
Is é Pól an t-aspal is
mó a d'fhág scríofa.
$\mathrm{COP}_{\mathrm{PRES}}$ he Paul the apostle $\mathrm{COP}_{\mathrm{PRES}}$ more $\mathrm{C}$ leave $\mathrm{PST}_{\mathrm{PT}}$ writings

'Paul is the apostle who has left the most writings.' (lit. 'Paul is the apostle who is biggest/most who has left writings') (Ó hAnluain 1999: 113-114, $\S 11.36$ [1960: 125-126, §225]; author’s trans.)

In summary, these examples do not establish exceptions to the standard construction of adjectival clefts, because the expected nasalising relative would at any rate have been superseded by a leniting one only secondarily as the result of syntactic 'raising'.

\subsection{Mixed antecedents}

A construction with mixed antecedents was already seen in (14) above, to be read as ba in[d] fortgidiu , ba hi temul du-gnith saul ..., 'it was covertly and it was in darkness that Saul ... used to make ...' (Ml. 30 3 3), where the nonrelative verb du-gnith follows the construction required by the surface-antecedent 
closer to it, hi temul, i.e. the adverbial cleft without a relative main verb, while the first surface-antecedent was adapted to this construction by being turned into a fronted adverb that is not otherwise admissible. A different case of mixed antecedents may be found in:
cid dian cian nothéisinn
although-COP ${ }_{\text {3SG.PST.SUBJ }}$ swift $_{\text {NOM.SG.NEUT }}$ and far $_{\text {NOM.SG.NEUT }} \mathrm{PV} \cdot{ }^{\text {LEN }}$ go $_{1 \text { 1SG.PST.SUB] }}$ 'though I went fast and far' (Ml. 41 $\left.{ }^{\mathrm{d}} 9\right)$

According to GOI $(\S 506)$, the leniting relative here is one of the rare innovative deviations from the nasalising relative rule, which will be addressed in section 6.2. However, while the first antecedent is the straightforward equivalent of an adverb in other languages - entailing an adjectival cleft *cid dían no-téisinn, 'though it was fast how I went' - this is not the case with cian: while one can go swiftly/in a swift fashion, one does not go in a far fashion, but rather a long distance. This semantic difference necessitates understanding cían as a substantivised $^{38}$ adjective, with an ensuing object relative, and for the latter, a leniting relative is one of the two options, i.e. *cid cían no théisinn, 'though it was a long distance that I went'. Here, too, then, the relative construction agrees with the second, closer, antecedent. ${ }^{39}$

\title{
5.4 Failure to mark relativity in a preverb
}

\author{
(89) iscián \\ $\begin{array}{ll}\text { arfolmas } & \text { dún } \\ \text { PV·undertake } & \\ \text { 3SG.PRET.PASS } & \text { for }_{1 \mathrm{PL}}\end{array}$ \\ $\mathrm{COP}_{\text {3SG.PRES }}=$ long $_{\text {NOM.SG.NEUT }}$ \\ insin \\ The $_{\text {NOM.SG.NEUT }}=$ that $_{\text {NOM }}$ \\ 'It is long since that has been destined (has been imminent) for us. ${ }^{40}$ \\ (Wb. 21 ${ }^{\mathrm{a}} 2$; author's trans.)
}

\footnotetext{
38 This is not the same as cían in its common use as a temporal noun 'long time' (cf. section 4.1 above, and also [89] below), inflected as an $\bar{a}$-stem rather than with neuter $o$-infection more typical of substantivised adjectives. And while one does not go in a far fashion, one can of course go in an extended fashion, i.e. for a long time, which allows the option of an adjectival antecedent in section 4.1 above.

39 When this paper was delivered at the original conference, Ruairí Ó hUiginn raised the valid objection that there are semantic limits to the pairing of mixed antecedents, so that disparate combinations he exemplified by 'It was quickly and dinner I was eating' are unlikely to occur. The same semantic discrepancy, however, is not found in the present case, nor is it in (14) above. 40 Already listed as (23) above (see there for further details).
} 
According to GOI (§ 493.4), "the pretonic prepositions im(m)• and ar have disyllabic forms in relative clauses: imme• or imm•, ara· (arch. are•)". From this, it would have to be inferred that ar-folmas in (90) is non-relative. However, while a secondarily shortened (syncopated) form ar- is limited to position before proclitic ro, relative ar-is occasionally encountered elsewhere, including at least once in Wb., ${ }^{41}$ compare the following complete collection:

(90) a. $\operatorname{ara} \cdot$ :

ara.lègthar $\left(9^{\mathrm{b}} 3\right)$, ara $\cdot$ thá $\left(10^{\mathrm{b}} 3\right)$, ara $\cdot$ foim $\left(13^{\mathrm{c}} 24\right)$, ara.bágim-se $\left(16^{\mathrm{d}} 9\right)$, ara.clessid $\left(22^{\mathrm{d}} 18\right)$, ara $\cdot$ neutsa $\left(23^{\mathrm{b}} 27\right)$, ara $\cdot$ mbere $\left(28^{\mathrm{c}} 11\right)$, ara $\cdot$ nethem $\left(31^{\mathrm{c}} 17\right)$

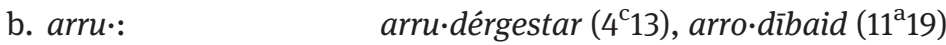

c. ara.r- (other than $\cdot r o-)$ : ara $\cdot r e t h i\left(6^{\mathrm{b}} 22\right)$

d. ara.ro-:

ara.rograd $\left(3^{\mathrm{c}} 25\right)$, ara róit $\left(4^{\mathrm{b}} 19\right)$, ara.rogartsom $\left(5^{\mathrm{c}} 23\right)$, ara.rogartsom $\left(5^{\mathrm{c}} 23\right)$, ara.róitmar $\left(9^{\mathrm{c}} 10\right)$, ara.róit $\left(9^{\mathrm{c}} 10\right)$, ara.roéit $\left(24^{\mathrm{a}} 32\right)$

e. ar.ro-: amal ar.rograd $\left(9^{\mathrm{b}} 13\right)-$ contrast $3^{\mathrm{c}} 25$ in (91d).

f. $\operatorname{ar}:$ : Ished ar.thá

for $\mathrm{COP}_{3 \mathrm{SG} . \mathrm{PRES}}=\mathrm{it} \mathrm{PV} \cdot{ }^{\mathrm{LEN}}$ remain $_{3 \mathrm{SG} . \mathrm{PRES}}$ insō the $=$ this $_{\mathrm{NOM}}$

'It is this that remains.' (30 $\left.{ }^{\mathrm{d}} 13\right)-$ contrast ished insō ara·thá $\left(10^{\mathrm{b}} 3\right)$.

While (90e) is merely more likely to be relative than non-relative, ${ }^{42}$ (90f) is unambiguously relative judging by both its context and the overtly marked relative lenition and shows - unless dismissed as a copying error - the incipient spread of the more common form ar- at the expense of relative ara-. Accordingly, ar-folmas in (89) could be taken as an innovative variant (cf. Ó hUiginn 1986: 65) for overtly relative ara-folmas.

41 See GOI (§ 493.4, note) and, for Ml. in particular, Strachan (1903a: 68) concerning cases of ar- before $r o$; his collection does not differentiate between stressed and proclitic $r o / r u$, and furthermore Ó hUiginn (1986: 65-66).

42 Compare the findings summarised by Ó hUiginn (1986: 56), according to which "where the verb which follows ama(i)l is not in the past subjunctive mood, relative marking is normal", accounting for seventy-seven cases in the glosses, as against fifteen classified as non-relative - six of the latter, however, merely show a non-third person class A infixed pronoun (Wb. $2^{\mathrm{a}} 11,14^{\mathrm{b}} 13$, $16^{\mathrm{a}} 2,17^{\mathrm{b}} 10,27^{\mathrm{d}} 19, \mathrm{Ml} .53^{\mathrm{b}} 18$ [if emended correctly]), a feature that is here rather taken as inconclusive as to relativity (see section 5.1), and only $16^{\mathrm{a}} 2$ clearly attests to non-relative status by using the independent negative (amal ninfessed). 


\section{Exceptions to the nasalising relative construction}

In remains to consider a small number of examples that apparently feature an unambiguously non-nasalising or even non-relative verb. Some or all of these were already noted by Pedersen (1899: 391, 413, 414), Mac Coisdealbha (1998: 155; cf. Isaac's comment in the same book, p. 257) and Ó hUiginn (1986: 48-58), without, however, distinguishing them from cases with non-third person class A infixed pronouns like (71) and (72) (on which see section 5.1), and $\mathrm{Wb}$. 6c8 adduced as a counterexample by Mac Coisdealbha ${ }^{43}$ instead contains an object antecedent (see [12] above). ${ }^{44}$ This leaves five cases: (91), (92), (100) to (102). ${ }^{45}$

\subsection{Third-person class A infixed pronoun}

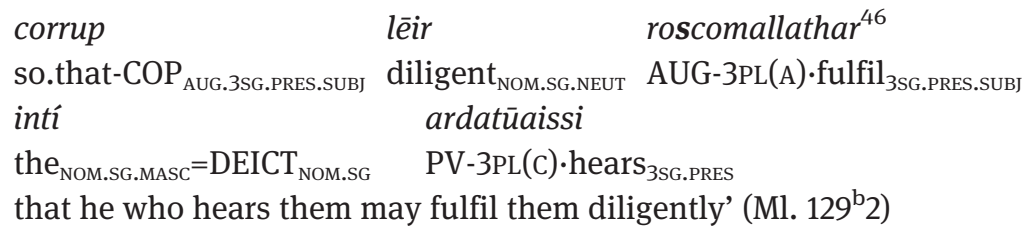

In line with Thurneysen's (GOI §413) ruling that in relative clauses, Class C "regularly replaces the pronouns of class A in the third person only" (for other persons, compare section 5.1), -s- here appears to point to a non-relative verb. On the other hand, Thes. 1: 724 (addendum 440) adds: "for the irregular $s$ in roscomallathar $\mathrm{cf}$. Wb. $9^{\mathrm{c}} 11, \mathrm{BCr} .10^{\mathrm{b}} 10^{\prime}$ - recte:

43 Isaac (in Mac Coisdealbha 1998: 257) accidentally quotes $6^{\mathrm{c}} 9$ instead.

44 Another counterexample only tentatively invoked by Pedersen $(1899: 391,413)$ is to be interpreted differently: cid beicc daucbaidsi, 'though it be of little worth, ye will understand it,' (Wb. 21 ${ }^{\mathrm{c}} 12$ ) (cf. Thes. 1: 634, n. e).

45 That is, still more than allowed for by Sims-Williams (1984: 193): “counter-examples are dubious (the best is Wb 1329)."

46 On the use of $r o$, Thes. 1: 440, n. c. notes, "In sentences of this type I have no other instances in the Glosses of ro- with the second verb ... Probably noscomallathar should be restored.” 
(92)

ishé cruth insō ærm nosmessammar

$\mathrm{COP}_{3 \mathrm{SG} . \mathrm{PRES}}=$ he way $_{\text {NOM }}$ the=this NOM $_{\text {NOM }}$ truly PV-3PL(A).judge ${ }_{1 \mathrm{PL} . \mathrm{PRES}}$

'This, truly, is the way we shall judge them.' (Wb. 9' ${ }^{\mathrm{c}} 10$ ) (on nosmessammar, Thes. 1: 553, n. c notes, "leg. nommessamar?")

(93)
anduslēicet
inna
rind
when ${ }^{\text {NAS }}$ PV-3PL(A) $\cdot$ sink $_{3 \text { PL.PRES }}$ the ${ }_{\text {NOM.PL.NEUT }}$ planets NOM.PL. $_{\text {. }}$
'when the planets sink' (Thes. 2: 11 [Carlsruhe Bede 18 ${ }^{\mathrm{b}} 10$ ])

The crucial question in order to assess (91) is whether the verbs in (92) and (93) are unambiguously relative. In Ó hUiginn's (1986: 56-58) assessment, “(In) $C(h) r u t h$ " with a relative verb is found six times in Wb., three times in Ml. and five times in Sg., as against six non-relative cases in Wb. (including 92 above), but none in Ml. and Sg. However, while the present case features cruth in the nominative, after which an adverbial nasalising relative connection ('by which') should at least be an option, the other five non-relative cases all show the dative in chruth-sin 'in that way' (Wb. $3^{\mathrm{d}} 27,18^{\mathrm{b}} 16,24^{\mathrm{a}} 17,24^{\mathrm{b}} 13$ ) or in chrud-so 'in this way' (Wb. 31 $\left.{ }^{\mathrm{c}} 11\right)$ fronted in a cleft sentence, i.e. with an adverbial surface antecedent, after which a non-relative verb is the norm anyway in Old Irish. While the difference between cruth and in chruth is duly pointed out by Ó hUiginn (1986: 56-57, cf. 65, 66), he includes the five examples with adverbial in chruth because the nasalising relative occurs once:
(94) hōre isinchruthso rumboī
because $\mathrm{COP}_{3 \mathrm{SG} . \mathrm{PRES}}$-the $\mathrm{DAAT.SG.MASC}=$ way $_{\text {DAT }}=$ PROX AUG. ${ }^{\text {.AS }}$ be $_{3 \mathrm{SG} . \text { PRET }}$
dossom
$\mathrm{to}_{3 \mathrm{SG} . \mathrm{MASC}}=3 \mathrm{SG}_{\mathrm{MASC}}$
'because it is thus that he has been' (Wb. $\left.33^{\mathrm{b}} 1\right)$

However, the latter is a special case due to syntactic raising (cf. section 5.2, as well as possibly [108] below): while the pattern of an adverbial cleft regularly demands a non-relative verb, i.e. *is in chruth-so ru boi do-ssom, the entire construction is here embedded into an hóre sentence, and the second part is then raised to depend directly on hóre, using the option of a nasalising relative (cf. e.g. hüare romboī, 'because it was,' [Ml. $\left.48^{\mathrm{d}} 8\right]$ ]).

As for $a^{n}$ 'when,' Ó hUiginn (1986: 46-47) counts five cases with a relative verb from $\mathrm{Wb}$., one hundred and twelve from $\mathrm{Ml}$. and fourteen from Sg., as against seven non-relative ones from Ml. and one from Sg. Of these, however, five merely 
feature a class A (non-third person) or B infixed pronoun, ${ }^{47}$ for which see section 5.1 above, and two could instead show phonological loss of an interconsonantal nasal. ${ }^{48}$ This leaves only one assured exception,

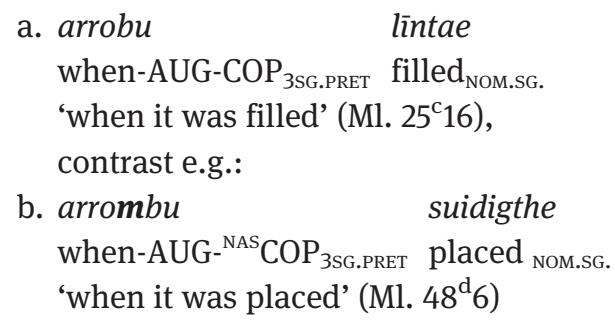

It is to be noted, however, that the verb in (95) is the copula. Ó hUiginn (1986: 66) has not only shown that among all patterns that at least allow an adverbial nasalising relative, "by far the greater part of the clauses which use [parataxis] contain the copula" but also argues that "the use of the nas. rel. seems to have progressed much more slowly in clauses containing the copula than it did in other clauses . . . [thereby] preserving the older parataxis for longer". Exceptions featuring the copula thus may represent one specific systematic deviation from the use of a nasalising relative, as allowed for in GOI ( $(505)$, rather than innovations as part of the beginning demise of this construction as documented in GOI ( $§ 506)$.

Thus, after $a^{n}$, the regular construction with stressed verbs is indeed the nasalising relative. As for cruth, and discounting instances of in chruth in adverbial clefts, all other cases listed by Ó hUiginn (1986: 56-57) are relative, ${ }^{49}$ establishing the nasalising relative as the mandatory construction. ${ }^{50}$ Examples (92) and (93), therefore, are valid parallels for the rare, or incipient, use of the third-person class A pronoun -s- in a relative verb, and for (92) in particular, the application of

47 anatammresa (Ml. 31 $\left.{ }^{\mathrm{c}} 14\right)$, andumsennat (39 28$)$, annumfindbad(a)igtisse (39 14 ), animmuntimchella $\left(108^{\mathrm{a}} 9\right)$, anaramrōet $\left(131^{\mathrm{b}} 8\right)$.

48 an as[n?]glinn (Ml. 70 12 ), anas[m?]berrat (Sg. 40 $\left.{ }^{\mathrm{a}} 15\right)$; see the discussion in last paragraph of the introduction and especially fn. 6 .

49 One of Ó hUiginn's (1986: 53) cases, cruth ropridchissem 'how we have preached' (Wb. $24^{\mathrm{C}} 17$ ), is not overtly marked as relative, but formally compatible. The antecedents in the remaining cases are either cruth or dative (in) chruth, but the latter is not part of a cleft construction, cf. in chruth nandrann insce, 'as . . . is not a part of speech' (Sg. 221 $1^{\mathrm{b}}$ ); ciachruth nombiad 'how could He be' (Ml. 17 $\left.{ }^{\mathrm{b}} 26\right)$.

50 The same is to be observed, without exception, for other nominal antecedents in manner clauses, see Ó hUiginn (1986: 56-58). His one reported deviation (Ó hUiginn 1986: 57, see also 50) is in fact also relative: inmét beta fírén in dóini 'in proportion as men are righteous' (Ml. 56 20). 
the double-article rule in ishé cruth . . . can be taken as additional evidence for a close, relative connection of the following verb. ${ }^{51}$ Accordingly, while corrup leir roscomallathar in (91) could be counted as a rare exception in deviating from the requirement of a (nasalising) relative in an adjectival cleft, it could also be taken as a similarly rare case of the third-person (-s- in particular $)^{52}$ class A pronoun in a functionally (though formally unmarked) nasalising relative verb. Additional support for the second interpretation may be seen in the fact that (91) (= Ml. $129^{\mathrm{b}} 2$ ) is paired with $129^{\mathrm{b}} 1$ - with these two glosses glossing two parallel Latin phrases - and the latter shows an overt nasalising relative: coru[p]léir dungné nech inpreceupt $\left(\mathrm{Ml} .129^{\mathrm{b}} 1=\right.$ [57]) above. A second isolated example featuring a third-person class A pronoun is:

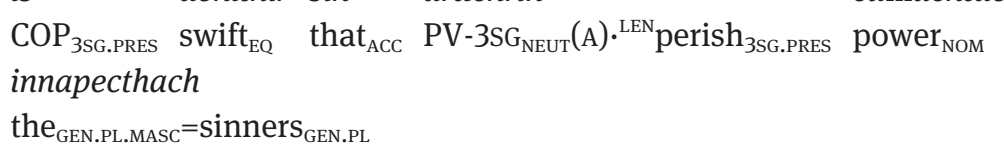

'Even so swiftly does the power of sinners perish.' (Ml. $57^{\mathrm{C}} 12$; also listed as an exception by Ó hUiginn 1986: 58, n. 35)

This is to be contrasted with the explicitly relative class $C$ pronoun e.g. in:

$$
\begin{aligned}
& \text { amal arindchrin dǽ }
\end{aligned}
$$

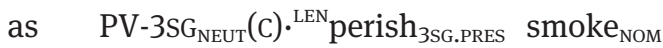

$$
\begin{aligned}
& \text { 'as smoke perishes' (Ml. 57 }{ }^{\mathrm{a}} 10 \text {; cf. Wb. } 27^{\mathrm{b}} 1,32^{\mathrm{c}} 10 \text {, Ml. } 85^{\mathrm{d}} 10 \text { ). }
\end{aligned}
$$

The apparent counter-examples are the following:

(98) fobithin arachiurat

because $\mathrm{PV}-3 \mathrm{SG}_{\mathrm{NEUT}}(\mathrm{A}){ }^{\mathrm{LEN}}$ perish ${ }_{3 \mathrm{PL} . \mathrm{FUT}}$

'because they will perish' (Ml. 59 $\left.{ }^{\mathrm{b}} 9\right)$

51 See Uhlich (2013) (pace GOI § 471).

52 In this connection it is significant that, however rare -s- is in relative clauses in Old Irish, this very use must have formed the basis for -s- developing into a mere relative marker in Middle Irish, for which see Strachan (1904: 169-170). And if accordingly, -s- is viewed as a low-register colloquialism (of the kind described by McCone 1985), it is paralleled by what appears to be an early case of hypercorrect use of $r o$ for no (for this more widespread feature in Middle Irish, see Breatnach 1994a: §§ 11.4-11.5; McCone 1997: 189-190, 197). 
(99) intan aracrínat

when $\mathrm{PV}-3 \mathrm{SG}_{\mathrm{NEUT}}(\mathrm{A}) \cdot{ }^{\mathrm{LEN}}$ perish ${ }_{\text {3PL.PRES }}$

'when [they] perish' (Ml. 73c 2; GOI § 423)

They differ from (96) in that they are readily explicable by the general exception described in GOI (§505). ${ }^{53}$ As for (96), this gloss also contains the same construction with a clear relative construction in amal as ndīan ade ${ }_{7}$ as ngair $\mathbf{m b i s}$ 'as it is swift and lasts for a short time', Ml. 57'12 (= 107 below), even though in the latter, mbis could also have been created by syntactic raising to be construed directly with amal (see section 5.2, and example 94). At any rate, a special explanation is required for (96), and a plausible factor to have caused the use of class A - $a$ - rather than class C $-(n-) d$ - may be seen in the fact that $a r a \cdot c h$ rin is one of a handful of Old Irish verbs that feature a petrified infixed pronoun, whose meaning and function ceased to be understood synchronically, so that the basic lexeme could be viewed, and generalised, as ara.chrin rather than ${ }^{*}$ ar.crin. ${ }^{54}$

\subsection{Absence of feasible relative nasalisation}

The considerations presented in section 6.1 leave the following three cases:

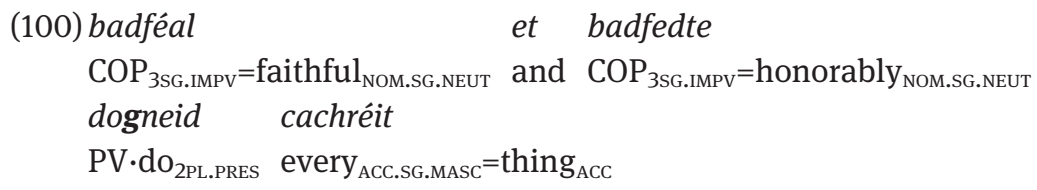

'Let it be faithfully and let it be honorably [?] that ye do everything.' (Wb. 13 ${ }^{\mathrm{a}} 29$ )
(101) cid
toīsigiu doberthar
although-COP ${ }_{\text {3SG.PRES.SUBJ }}$ first $_{\text {COMP }} \mathrm{PV} \cdot \mathrm{do}_{3 \mathrm{SG} . \text { PRES.SUBJ.PASS }}$

\footnotetext{
53 While relative hore arinchrinat 'because they decay' (Wb. $\left.27^{\mathrm{b}} 1\right)$ is of course also possible. 54 See GOI (§ 423). An alternative explanation is implied by Thurnysen’s description (GOI $\S 423$ ) of intan aracrinat in (99) as simply 'without $d$ ', i.e. as if ara- were here the relative form of the simple preverb without any pronoun attached. However, this is contradicted by the lenition spelled out in (98), which points not to a nasalising relative as an option after such conjunctions, but to the presence of a neuter pronoun. Thus, leg. ara-c[h]rinat with standard defective spelling.
} 


\section{indfochaid}

the $_{\text {NOM.SG.FEM }}=$ tribulation $_{\text {NOM }}$

'though the tribulation is inflicted first' (Ml. 19 $\left.{ }^{\mathrm{b}} 11\right)$ (see Thes. 1: 716 [addendum 26.24])

(102) airismōu ruicim les mairchissechtae indaas for-COP SSG.PRES $_{\text {more }} \mathrm{PV} \cdot$ reach $_{1 \mathrm{SG} . \mathrm{PRES}}$ need $_{\mathrm{ACC}} \mathrm{my}=$ pitying $_{\mathrm{GEN}}$ 'than' 'for I need to be pitied rather than . . ' (Ml. 22 ${ }^{\mathrm{C}} 14$ ) (cf. also section 4.2; for airismōu manuscript has airimmou)

In all three examples, "the opportunity to nasalize was not taken" (Isaac, in Mac Coisdealbha 1998: 257, commenting on [100]). Thus, these adjectival cleft sentences clearly do not use a nasalising relative, but the question is, what do they use instead? If Thurneysen's observation were applied, according to which "a nasalizing relative clause can be replaced by a formally independent (i.e. principal) clause in almost every instance” (GOI $§ 505)$, all three main verbs above would have to be taken as non-relative. As Ó hUiginn (1986: 66) has shown, this type of systematic exception is predominantly found with the copula. Furthermore, since none of these forms can be proven by their orthography to be non-relative, ${ }^{55}$ the alternative is to take them as leniting relatives. Rather than systematic exceptions, then, these may be isolated examples of the incipient "extension of the leniting at the expense of the nasalizing relative" that will be completed by the end of the Middle Irish period (Ó hUiginn 1986: 70; see also 69-75 for more details; also GOI §506).

\section{Conclusions}

Having thus reviewed almost the entire evidence for the construction of adjectival cleft sentences - apart from one special environment to be addressed in the appendix - it emerges (section 4) that the vast majority of examples either shows overt marking of relative nasalisation, or the spelling is at least compatible with this construction - be it ambiguous merely orthographically ${ }^{56}$ or also phonologically. ${ }^{57}$ Section 5 addresses a number of formal deviations that are

55 Contrast, for instance, the unambiguous difference, with a simple verb, between relative hōre pridchas 'because he preaches' (Wb. $\left.7^{\mathrm{b}} 15\right)$ (vs. non-relative pridchaid) and non-relative hōre pridchim 'because I preach' (Wb. $5^{\mathrm{c}} 6$ ) (vs. relative no pridchim).

56 Such as adcotar in (39), where the $<\mathrm{c}>$ can represent non-relative /k/ or nasalised /g/.

57 Such as dorigni in (46), where the $/ \mathrm{r} /$ is not capable of being nasalised. 
argued to be due to additional factors (syntactic raising, mixed antecedents), formal innovation (relative ar- replacing ara-) and, to begin with, the use of nonclass $\mathrm{C}$ infixed pronouns. These are formally incapable of marking relativity, ${ }^{58}$ but are regularly admissible (except for class A third persons) nonetheless in indisputably relative contexts like the mandatory leniting relative after a subject antecedent. Therefore, their presence alone cannot serve to prove that the verbal form that contains them is functionally non-relative. In other words, while e.g. third person singular beires 'who carries' is exclusively relative vs. beirid 'carries' exclusively non-relative, the same distribution is valid for, say, nasalising relative do-mbeir 'by which . . . brings' vs. non-relative do-beir (with /b/) 'brings', but not for the pair dondom-beir 'by which . . . . brings me' vs. dom-beir, since the latter is found for both 'brings me' and 'by which . . . brings me'. Relative forms like dom-beir may still, it is true, be classified as a type of exception, if viewed from the diachronic perspective described by Ó hUiginn (1986: 67):

It has been held that the creation of the class $\mathrm{C}$ inf. prons. represents a relatively late development in the prehistory of Irish and grew out of a need to formally distinguish rel. clauses ... Pronouns of the first and second persons seem to have been much slower in adopting the new rel. forms . . .

In this scenario, the exception consists in not creating the opportunity for the formal marking of underlying relativity by introducing a class C pronoun. Relativity unmarked, however, does not equal non-relativity, ${ }^{59}$ and synchronically, such forms will still not fall under the rule that "a nasalizing relative clause can be replaced by a formally independent (i.e. principal) clause" (GOI $\S 505)$, as is the case e.g. for Thurneysen's example hóre ni-ro•imdibed with its unambiguously non-relative negative ní. Therefore, the use of non-class C pronouns (apart from third persons class A) is here treated as formally inconclusive as to relativity and thus does not constitute an assured exception to the use of a nasalising relative in adjectival clefts.

This left only five possible counterexamples (section 6), but even these were argued to be explicable not as systematic exceptions, but as individual innovations affecting all types of nasalising relatives. The result of this study, then, is that Thurneysen's ruling that adjectival clefts trigger a mandatory (underlying) nasalising relative is to be upheld in principle, because there is no unambiguous evidence that a main-clause verb could be used instead.

58 Relative lenition and nasalisation can only be expressed, and only nasalisation be shown in writing, on the - $d$ - of a class C pronoun, cf. (26), (27), (32), (50), (54).

59 As it does not, either, with the phonologically ambiguous forms listed above, such as dorigni in (46). 


\section{Appendix: The main verb attá 'to be'}

A specific application of the adjectival cleft pattern remains to be considered, which is described by Thurneysen in a separate paragraph, namely "when the antecedent supplies the concept that constitutes the predicative nominative of the relative clause" (GOI $\S 500$ ). One of his examples involves an adjective, as in (105) below, resulting in an adjectival cleft as discussed here, with the only difference that the main verb is 'to be', specifically the substantive verb - literally 'it is $\mathrm{X}$ how $\mathrm{Y}$ is', etc. ${ }^{60}$ Still, two subtypes are to be distinguished:

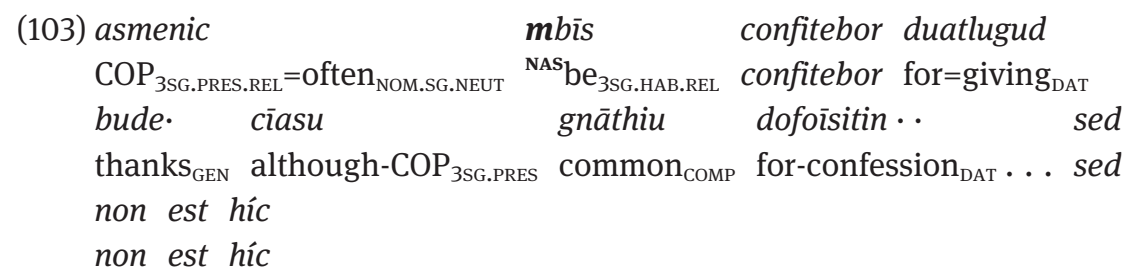

'that confitebor is often for returning thanks, though it is more common for confession, sed non est hic' (Ml. 26 $\left.{ }^{\mathrm{C}} 4\right)$

While all cases feature the substantive verb, this first example would do so even outside the cleft pattern. While structurally required by the prepositional predicate $d u$ atlugud, this is not immediately suggested by the copula continuation cīasu gnāthiu dofoissitin, but confirmed by the similar reference in:

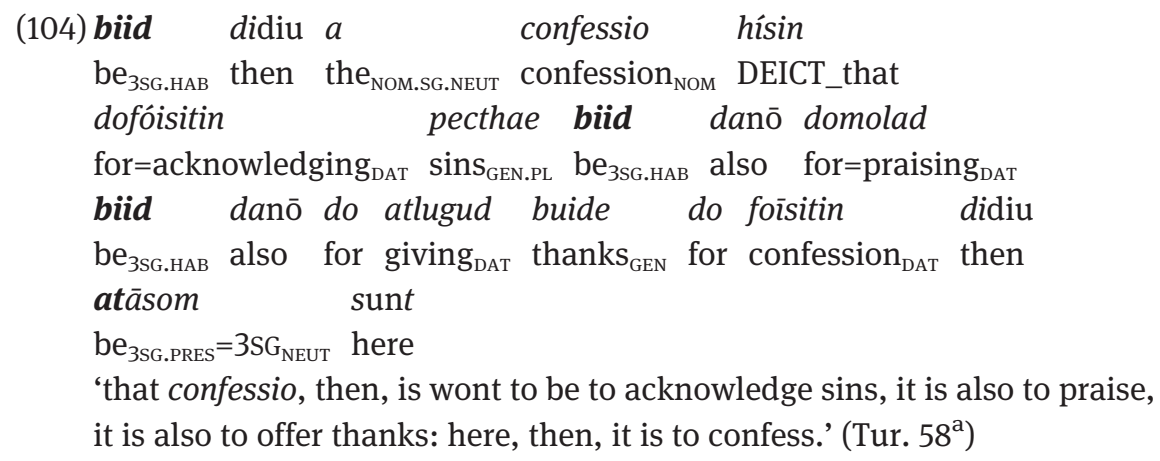

60 To the cases listed below might be added those in section 4.1.1 involving cían, if to be taken adjectivally. 
This means that cīasu gnāthiu dofoisitin in (103) must itself be an elliptical cleft sentence, for cīasu gnāthiu mbís . . . In the next three cases, however, the surface antecedent itself stands for the predicate of the following verb (as opposed to menic above with adverbial connection), which therefore must be used in place of the copula: ${ }^{61}$

(105) cid

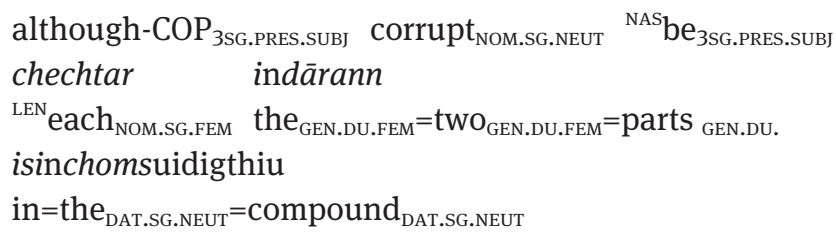

'though each of the two parts in the compound be corrupt' (Sg. 202 ${ }^{\mathrm{b}} 3$ )
(106) isfaittech

$\mathrm{COP}_{\text {3SG.PRES }}=$ careful $_{\text {NOM.SG.NEUT }}$

nant

neque

$\mathrm{NEG}_{\mathrm{SUB}^{-}}{ }^{\mathrm{NAS}} \mathrm{COP}_{3 \mathrm{GG} . \mathrm{PRES}}$ neque

rondboīsom

$\mathrm{AUG}^{-{ }^{\mathrm{NAS}}} 3 \mathrm{SG}_{\mathrm{NEUT}} \cdot \mathrm{be}_{3 \mathrm{SG} \text {.PRET }}=3 \mathrm{SG}_{\mathrm{MASC}}$

manebunt asrubart

'He was careful that he did not say neque manebunt.' (Ml. 21 $\left.{ }^{\mathrm{d}} 4\right)$

(107) amal as

\section{ndīan}

as COP $_{3 \text { SG.PRES.REL }}$ ngair

${ }^{\mathrm{NAS}}$ Swift $_{\text {NOM.SG.NEUT }}$

ade 7 as

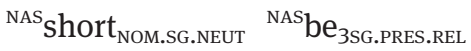

'as it is swift and lasts for a short time' (Ml. 57' 12 )

In the absence of evidence that the copula itself could also be used as the main verb in this construction, the following case from the Additamenta in the Book of Armagh seems puzzling:
(108) fer. . . nadip
rubecc
man $\mathrm{NEG}_{\mathrm{SUB}}-\mathrm{COP}_{3 \mathrm{SG} . \text { PRES.SUBJ }}$ nadipromār
too.little NOM.SG.NEUT
$\mathrm{NEG}_{\mathrm{SUB}}-\mathrm{COP}_{\text {3SG.PRES.SUBJ }}=$ too.great $_{\text {NOM.SG.NEUT }}$
bedasommæ
$\mathrm{COP}_{\text {3SG.PST.SUBJ }}$-his=wealth ${ }_{\mathrm{NOM}}$

61 For this and other regular uses of attá in place of the copula, see GOI (§774) and Mac Coisdealbha (1998: 154-155). 
'a man . . . whose wealth would not be overlittle or overgreat' (Thes. 2: 241.8-9 and 27-29) (cf. Bieler 1979: 176-177, § 13 [2]; ${ }^{62}$ note also that the example is glossed according to the traditional interpretation.)

Here, nadip clearly contains the third person singular present subjunctive of the copula, but what is bed $(a)$ ? The sequence bedasommæ (folio $18^{\mathrm{rb}} 15$ ) is reproduced as such in Thes., but edited as bed a sommæ by both Bieler (1979: 177) and Thurneysen (1949: 33), in which bed could be the third person singular past subjunctive (or conditional) relative of the copula. On the other hand, since all parallel instances above feature the substantive verb, one could instead assume a third person singular past subjunctive of attá, standing for no beth/bed with omission of no. ${ }^{63}$ However, this would still leave a problem of concord, according to which the present subjunctive in nadip would be expected to be matched by the main verb of the cleft construction. ${ }^{64}$ A solution may be proposed that will begin by considering the word sommae. This is given in DIL (s.v. 1 sommae, 'riches, wealth') as an iā-stem connected with soim 'rich, wealthy,' implying a standard abstract formation. Thurneysen, on the other hand, lists it as 'Subst. neut.' (1949: 103). Among the attestations in DIL for both sommae and its counterpart 2 dommae 'poverty, scarcity,' there is no evidence to ascertain the gender of either in Old Irish. ${ }^{65}$ Moreover, besides the adjectives soim and doim, there are also 2 sommae 'rich, wealthy' and 1 dommae 'poor, needy,' and on the other hand there are also sommatu 'wealth, luxury' and dommatu 'poverty, want.' This makes a derivational relationship soim $\rightarrow$ abstract noun sommae and doim $\rightarrow$ dommae far less obvious, and if an original semantic difference between abstract sommatu 'the status of being rich' and concrete sommae 'riches', etc., can be assumed, sommae and dommae are neuter nouns subtantivised directly from the homonymous adjectives. In this case, sommæ in (108) could be singular or plural, and for the use of the latter - including a concrete meaning - compare marba sommai 'goods will be destroyed' (Meyer 1894: 40.9.13). This in turn opens up the option of taking the verb in bedasommæ as plural, too, and I suggest the following derivation that solves

62 This phrase has no equivalent in the corresponding passage in the Vita Tripartita, see Stokes (1887: 188.26-27), Mulchrone (1939: lines 2221-2212).

63 Cf. combed hed nobed and, 'so that that should be there' (Wb. $\left.3^{\mathrm{b}} 10\right)$. For the omission of no see Kelly (1999). Mac Coisdealbha (1998: 154) lists this as one of three cases that show "the substantive verb in place of the copula" but does not explain the form.

64 Apart from cases where the introductory copula is reduced to "the unmarked, neutral present tense" (see Mac Coisdealbha 1998: 144-145).

65 Dinneen's (1927) “soime . . f., riches” could of course continue either gender. 
both problems, that of the verb 'to be' and that of concord: assuming that bedasommæ is among the numerous cases in the Additamenta that reflect an Early Old Irish spelling, its original shape may have been *bede e somme, involving a third person plural present subjunctive relative of attá, which in (Classical) Old Irish is spelled bete. ${ }^{66}$ This was misunderstood by a subsequent, Old Irish scribe, who, instead of modernising it correctly to *bete a sommæ, adapted it mechanically to bed a sommæ. And returning to the construction under discussion, a separate 'it should not be too little nor too great that his riches are' would be expected to be construed with nasalising relative, i.e. *nip rubecc nip romar ( $m$ )bete a sommæ. That the $b$-is not nasalised may be due to one of two reasons: either, this text is simply too early for relative marking to have been analogically transferred to the initial of simple relative forms. ${ }^{67}$ Or, as Elliott Lash has suggested to me, this may be yet another case of syntactic raising (cf. section 5.2 and [94]), in which expected (m)bete was raised to the level of the preceding genitival (leniting) relative nadip . . ., as if depending directly on the superordinate antecedent fer. Be that as it may, the resulting merged syntagm, which subordinates the adjectival cleft construction 'it should not be too little or too great that his riches are' to the genitival antecedent 'a man (whose)', cannot be represented literally in English. As possible approximations, however, the following may be suggested, namely either (a) 'a man concerning whom it should not be too little or too great that his riches are (or: ... too great whose riches are)', thereby compromising on the genitival relative connection, or (b) 'a man whose riches should be such that they are not too little or too great', with a freer rendering of the clefting construction.

$66 \mathrm{Cf} . \mathrm{Wb} .10^{\mathrm{c}} 22$. For the earlier spelling convention of mediae for non-initial voiced stops, cf. scarde, 'who separate' (Thes. 2: 247.18 and 39 [Cambrai Homily]), adobragart (Wb. $19^{\mathrm{b}} 5$ [prima manus]), 'has seduced you' (cf. GOI §31, note).

67 Cf. GOI (§ 495 [b]) for lenition, (§504 [c]) for nasalisation. 
